\title{
PENSION REFORM 2019: \\ DETERMINANTS, CONSEQUENCES, ALTERNATIVES
}

\author{
$\underline{\text { SERGEY IVANOV }}$
}

\begin{abstract}
The paper addresses, mostly with demographic tools, the rationale and consequences of the reform of Russia's distributive pension system. Contrary to official assertions, mortality conditions do not warrant an increase of the pension age. The reference to a rapidly falling demographic support ratio as a rationale of the reform's urgency is misleading. A rapid and large increase in the retirement age will considerably reduce the obligations of the Pension Fund of Russia, yet this will be far from enough to balance its budget. The reform creates a fundamentally new and difficult to implement task of ensuring the right to employment of persons deprived of the right to a pension. To the extent that this task can be accomplished, the Pension Fund of Russia and the State budget will be supplemented with additional revenues. At the same time, to the extent that this task remains unresolved, a social group of elderly people who are deprived of income will arise and continue to grow. For a limited time their life will be supported by unemployment benefits. Russia possesses large-scale alternative resources for resolving the pension problem, which consist, among other things, in increasing the collection of pension contributions, labor productivity and employment of the population, as well as in developing funded forms of pension insurance.
\end{abstract}

Key words: population ageing, mortality, compulsory pension insurance, distributive pension system, statutory pension age, Pension Fund of the Russian Federation, working-age population, employment, pension reform, sovereign wealth fund.

In recent decades, many countries of the world have faced a problem financing distributive pension systems as a result of "double aging": the aging of the population and the aging of the pension systems themselves, which are less and less in line with the changing age structure. Pension reforms round out funded components and change the ratio between the resources of pension systems and their obligations by raising the retirement age (RRA). Although there is a wide consensus on the general principles of pension system reform, the correct structure and parameters of the reform are highly dependent on specific circumstances (Holzmann, Stiglitz 2001; Schwarz 2014). Along with the predominant preference for a three-tier pension system (distributive, mandatory funded and voluntary funded), there exists a point of view that for the post-Soviet space in the medium term, a distributive system is optimal (Grishchenko 2016).

There are many foreign precedents for raising the retirement age. Typically, a reform is preceded by a broad discussion of the purpose, scope, implementation protocol, and consequences of RRA (Grech 2014). The RRA itself does not exceed two years and is stretched out over time. In addition, mechanisms are developed to automatically adjust the parameters of the pension system (retirement age, pension, resources) in the future following eventual demographic shifts (Carone et al. 2016). Such mechanisms help to avoid abrupt changes in the pension system and strengthen citizens' trust (Arbatli et al. 2016).

SERGEY IVANOv (sfivanov84@gmail.com), Lead Research Fellow, Institute of Socio-Political Studies, Russian Academy of Sciences, RUSSIA.

THE ORIGINAL ARTICLE IN RUSSIAN WAS PUBLISHED IN DEMOGRAPHIC REVIEW 2019. 6(2): 6-54. DOI: 10.17323/DEMREVIEW.V6I2.9871. 
The Russian pension reform of 2019 differs from these approaches in cardinal ways. The main difference lies in the combination of an unprecedentedly large RRA with the very high speed of its implementation. Another important difference is that the sudden decision ${ }^{1}$ was not preceded by either a wide discussion or a preparatory period during which those affected by the future reform could adapt in advance to the change in their life trajectories (Remington 2018). Instead, the authorities announced only the goals of the reform: balancing the revenues and expenses of the pension system and using the savings to increase pensions. After the RRA was promulgated, the emphasis was shifted completely to incremental increases of pensions which, according to the authorities, would require large additional transfers from the federal budget - in addition to the money saved due to the RRA. Another difference of the Russian reform, which is mentioned at the end of the article, is that Russia has much greater unrealized potential than other countries for alternative ways to solve the pension problem.

The authorities justified both the possibility of and the necessity for RRA using only demographic arguments. The possibility of RRA was justified by increased life expectancy. The argument includes three points. Firstly, increased life expectancy means that the health of older citizens has improved so much that they are able to work longer. Secondly, life has become so long that at the current low retirement age, people live idle for too long, which is completely unfair and burdensome for the State. Thirdly, people themselves would like to work longer. As for the necessity of RRA, it was deduced from the assumption that the aging of the population completely determines the inability of the Pension Fund of the Russian Federation (PFR) to provide mandatory pension insurance (MPI) without supportive transfers from the state budget.

The following analysis of the factors determining the resource requirements and obligations of the Russian pension system and the forecast of the effects of RRA for the period 2019-2030 are based on data published by Rosstat ${ }^{2}$. An exception is demographic indicators borrowed from the United Nations Population Prospects. This exception is made because the UN publications describe in detail the methodology and the hypotheses, whereas one can only guess as to the reasons for even major revisions by Rosstat of its population projections. In addition, there is reason to believe that in its forecasts Rosstat uses unreasonably high hypotheses of the dynamics of life expectancy (and its components). Rosstat's hypotheses of net international migration which are higher than in the UN model are probably justified, but this does not balance other shortcomings. Forecasts of the size and age-sex structure of the employed population were obtained by combining Rosstat employment rates and the UN population projections (2017). The complexity of reproduction of specific groups of retirees (including early retirees) and those receiving pensions funded from the state budget (e.g. the military) as well as the incompleteness of data seriously restricts the predictability of their dynamics. In the following analysis, which, inter alia, aims to build a reliable forecast of the dynamics of the number of pensioners and

\footnotetext{
${ }^{1}$ Federal Law N 350-Ф3 “On Amending Certain Legislative Acts of the Russian Federation on the Appointment and Payment of Pensions" was adopted by the State Duma on September 25, 2018 in the third reading - less than 3.5 months after the bill was introduced by the Prime Minister (16 June 2018). Commentators, including government officials, usually called the bill a decision.

${ }^{2}$ Economic data are given for the following editions of Rosstat published in 2001-2018: Russian Statistical Yearbook; Labor force, labor and unemployment in Russia; Labor and employment in Russia; Social status and living standards of the population of Russia; Demographic Yearbook of Russia; Statistical Review; Labor force surveys; Information on the socio-economic situation of Russia.
} 
working-age population, it was necessary to make the assumption that all and only citizens of retirement age $\mathrm{e}^{3}$ receive an old-age insurance pension.

\section{THE DISTRIBUTIVE PENSION SYSTEM}

In the Soviet Union, a universal system of mandatory pension insurance (MPI) of a distributive type was created. In Russia, it remains absolutely predominant, i.e. a universal and quasimonopolistic form of old-age pension provision. The distributive system is based on the principle of payment of pensions for current pensioners from deductions from the income of workers, regardless of whether these deductions are explicit or hidden in other forms of redistribution of output. The peculiarities of the Soviet pension system were the low statutory retirement and the many exemptions from the general rules made on the basis of profession, geographical region, number of children or even ethnicity. For specific groups, a lower retirement age was established, which is explained by factors such as the danger and harmfulness of the profession (for example, miners), exposure to adverse environmental factors (regions of the Far North), the fulfillment of a particularly important social function that limits participation in the labor force (mothers of many children), and special benefits provided to indigenous peoples of the Far North.

The Soviet distributive pension system, including the features noted above, has survived in post-reform Russia. However, it differs significantly from the Soviet one in the following ways: (1) many pensioners receive basic old-age pensions below subsistence level; (2) territorial allowances have been introduced that raise pensions to the subsistence level or even to or above the national average pension; (3) pensions are indexed for inflation; (4) the MPI system is funded from several sources; (5) the complexity and opacity of changing pension rules make it difficult for citizens to plan their lives; (6) at the macro level, the flows of MPI system funds are also complex and opaque. Most functions of the Soviet social security agencies were transferred to the newly created Pension Fund of the Russian Federation (PFR), the sovereign extra-budgetary fund that manages the State pension system and is designed to ensure citizens' rights to pensions. The PFR collects deductions from the employer (pension contributions) for MPI and pays out pensions (previously, pension payments were made directly from the State budget) and receives transfers from the state budget.

Guaranteed retirement income upon reaching a specified age and regardless of the state of one's health is one of the obligations of the social State, which the Constitution of the Russian Federation considers it to be. Other countries have long followed this principle. In Germany at the end of the 19th century, as in other Western countries several decades later, universal pension systems were established on the basis of a high retirement age (usually 70 years without gender

\footnotetext{
${ }^{3}$ In other words, it is assumed that all citizens of retirement age receive an old-age insurance pension which is the function of their previous pension contributions. In fact 3.1 million people receive "social pensions" which do not depend on previous contributions and 0.7 million receive special types of State pension (as opposed to insurance pensions, the outlays for pensions of the latter two categories are directly financed by the federal government). Further, it is assumed that only citizens 55 years of age and older (women) and 60 years and older (men) (and of incrementally higher retirement age, as provided by the reform) receive old-age insurance pensions, while in fact a number of professions allow for earlier retirement with full benefits.
} 
difference); subsequently, this age was reduced to 60-65 years, which was one of the manifestations of the development of a society of social solidarity.

In Russia, the retirement age was established (1928) at 55 for women and 60 for men. It was recognized that upon reaching this age, every Russian has the right to receive a share of the public pie free of charge simply because he is a citizen of the Russian Federation ${ }^{4}$. In fact, the system became truly universal in the early 1960s when the coverage was extended to kolkhozniks (collective farmers). The right to an old-age pension is unconditional and universal. Although only insured persons who have accumulated "qualification rights" are entitled to an insurance pension, the State provides other types of pensions to all other citizens.

Although the right to retirement benefits is unconditional, the prevailing form of its implementation - old-age insurance pensions - implies the existence of a contractual relationship between the insured person and the insurer. An MPI agreement differs from other insurance contracts in that (1) the insurer is the State; (2) insurance is mandatory for all workers; (3) insurance conditions are determined only by the insurer; (4) State relations with citizens are not fixed in individual contracts but are implied. An implicit agreement with citizens is based on a perpetual explicit agreement between the State and society, an agreement enshrined in national law. In exchange for restricting the freedom of choice, the insured citizen receives a guarantee that the State as a whole, and not some of its specialized regulatory bodies, is responsible for financing their pension.

\section{MANDATORY PENSION INSURANCE IN RUSSIA}

The Russian national administrator of the pension system, the Pension Fund of the Russian Federation (PFR), has features that are relevant for the chosen way of adapting the pension system to changing conditions. The Pension Fund is the State monopoly regulatory organization for compulsory social insurance and, as a result, is the country's richest entity: its budget is more than 8 trillion rubles, which is equal to $1 / 10$ of the GDP of the Russian Federation. The fund serves 43.5 million pensioners, including 39.8 million recipients of insurance pensions, and administers insurance contributions of 9.3 million policyholders - legal entities making MPI payments at a rate of 22 percent of the payroll, as well as self-employed payers of pension contributions (Pension Fund 2018). In addition, the functions of the Fund include the administration of "social pensions" (to retirees who do not qualify for insurance pension) and some other benefits, in particular a large fund which underwrites the "maternity capital".

The PFR has over 100 thousand employees - far more than anywhere else in the world. For comparison, the American Social Security Administration has 60 thousand employees serving 61.5 million pensioners. If the pension system in Russia were as effective as, for example, Sweden's, it would require no more than 14 thousand employees to perform a wider range of

\footnotetext{
${ }^{4}$ Foreigners working in Russia also have the right to an old-age pension, but, due to the country-specific conditions of labor immigration, they very rarely manage to accumulate the required years and seniority points. As a result, foreign workers are a net source of income for the Russian pension system. On the other hand, the PFR pays various types of pensions to 328 thousand citizens living abroad.
} 
functions than the PFR currently performs. However, as follows from its annual reports, the Fund itself is pleased with both its work and the structure of the Russian pension system in general.

PFR annual reports contain more than 100 pages each, but only 4-5 pages have been allocated to the Fund's budget. The reports do not contain an actuarial analysis or other requirements of the international practice of reporting on sovereign pension funds. The PFR often revises budget indicators for previous years without explaining the reasons and methods of corrections, the sizes of which range from tens of millions to tens of billions of rubles. Not a single report after 2010 (the publication of online annual reports by the Foundation began in 2011) has mentioned a single problem that led to the 2018 decision on RRA. The Fund is not involved in the ongoing discussion on pension reform, although the PFR's leadership considers its public awareness work to be its particularly bright activity.

Of special interest in the PFR reports are the totals for revenues and expenses of the MPI system. Thus, the product of the number of people employed in the economy in 2016 (72 million people) by the average salary (408 thousand rubles per year) and the coefficient of deductions for MPI (22\%) gives 6.5 trillion rubles, while according to the PFR report MPI receipts of contributions came to 4.5 trillion rubles. Such a huge discrepancy can be explained by the fact that MPI contributions are not paid for many millions of employees, which should be an enormous problem, but about which the PFR is silent. Thus if this were the sole explanation for the discrepancy, the number of workers not covered by the MPI system would have to be 22 million. This implies that it is a question not only of ineffectiveness of the PFR, but a more general problem of systemic deficiencies of the tax system.

On the other hand, the product of the number of old-age pensioners ( 36 million people) and the average old-age pension (158 thousand rubles per year) turns out to be, on the contrary, almost 700 billion rubles less than the reported amount of pension payments ( 6.4 trillion), the reason for which is not only not explained by the PFR itself, but is altogether a mystery. As a result, the estimated budget would balance with a surplus of 0.8 trillion rubles as opposed to the reported deficit of 1.9 billion rubles). Undoubtedly, there should be a good explanation for this phenomenon, but it is strange that a public organization with resources representing a quarter of the State's consolidated budget did not anticipate our questions in advance. In the framework of the paradigm of the rational functioning of State institutions, it is also difficult to understand why the Audit Chamber of the Russian Federation never, even in the context of preparing the pension reform, conducted a general audit of the Fund.

Table $1^{5}$ contains data on the main parameters of the PFR budget that characterize the Russian distributive pension system. In 2011-2017, PFR revenues grew, adjusted for inflation, by $1.5 \%$ per year, and expenses by $3.5 \%$ per year. A surplus budget at the beginning of the decade

\footnotetext{
${ }^{5}$ Since it is not possible to correct the published data, budget indicators for the period 2010-2017 (table 1) are given according to PFR annual reports. The forecast of income and expenses for the income tax base is based on the demographic forecast and assumptions regarding economic parameters. Of course, it would be better to remove the inconsistencies in the budget data for 2016-2017 at the starting point of the forecast, but this is not possible. However, it should be emphasized that this drawback is unlikely to affect much either the logic of the proposed model or the relationships and trends it detects.
} 
in 2015 became acutely deficit; in 2016-2017 the deficit was drastically reduced, though no explanation was provided.

Table 1. Revenues and outlays of the Pension Fund of Russia in 2011-2017

\begin{tabular}{|c|c|c|c|c|c|}
\hline & \multicolumn{2}{|c|}{ Billion rubles } & \multirow{2}{*}{$\begin{array}{c}\text { Average annual rate } \\
\text { of change, } \%\end{array}$} & \multicolumn{2}{|c|}{ Growth for the period, $\%$} \\
\hline & 2011 & 2017 & & 2017 to 2011 & 2017 to 2015 \\
\hline $\begin{array}{l}\text { PFR revenues } \\
\text { Including }\end{array}$ & 5250 & 8250 & 7.8 & 57.1 & 15.8 \\
\hline MPI contributions & 2826 & 4482 & 8.0 & 58.6 & 16.0 \\
\hline Transfers & 2798 & 3671 & 5.6 & 31.2 & 18.4 \\
\hline Including to MPI & & 2213 & & & \\
\hline $\begin{array}{l}\text { PFR outlays } \\
\text { Including }\end{array}$ & 4920 & 8320 & 9.2 & 69.1 & 8.5 \\
\hline Pension payout & 4081 & 7167 & 9.8 & 75.6 & 16.0 \\
\hline Including to MPI & & 6378 & 5.0 & & \\
\hline PFR balance & & 330 & -70.0 & & -87.1 \\
\hline Including for MPI (before transfer) & & -1896 & & & \\
\hline NWF funds (for reference) & 2600 & 4385 & 9.1 & 68.7 & 4.4 \\
\hline
\end{tabular}

Notes:

- MPI: mandatory pension insurance, PFR: Pension Fund of Russia, NWF: National Wellbeing Fund

- The table shows the values of indicators adjusted by the PFR itself (in later Reports) if the adjustment did not violate the balance sheet ratios.

Sources: Pension Fund of the Russian Federation. Annual reports for 2011-17.

http://www.pfrf.ru/press_center/advert_materials 2074 (accessed 07.22.2018), Ministry of Finance of the Russian Federation. The movement of funds of the National Welfare Fund.

https://www.minfin.ru/en/perfomance/nationalwealthfund/statistics/\#ixzz5MGN4LLxD (accessed 20.07.2018)

The PFR's MPI outlays increased from 5.8 trillion rubles in 2015 to 6.4 trillion rubles in 2017 , i.e. the growth rate did not keep up with the inflation rate (5.0\% per year versus $5.7 \%$ ). The driver of spending growth during this period, as throughout the decade, was an increase in the number of pensioners, while pensions in real terms decreased. The amount of contributions to the MPI increased over the same period from 2.8 trillion rubles to 3.9 trillion rubles in 2015 and 4.5 trillion rubles in 2017, in other words, income from MPI increased throughout the entire period by an average of $8 \%$ per year, significantly (1.7 percentage points) above inflation. Available data show that at the turn of the century the PFR budget had a surplus of hundreds of billions of rubles. In the first half of the 2000s the surplus quickly melted away, and in 2015 turned into a huge deficit, which in the next two years also fell rapidly. Based on the generalized data on the expenditures of the Pension Fund and the high (about 80\%) share of its expenditures on MPI, it is reasonable to assume that the rapid reduction in surplus and its turning into a deficit was due to the deterioration of the balance of MPI flows precisely because of the population aging, provided that the collection of contributions didn't deteriorate.

The target transfer to the MPI in 2015 was 433 billion rubles less than the deficit of the PFR's own funds, in 2016 it just covered it, and in 2017 it turned out to be 317 billion rubles in excess. PFR reports do not explain the considerable excess of the target transfer over the need for it. This suggests that one should look for the potential of increased financing of the MPI in the Fund itself rather than rely on the NWF. 
Forecasting flows of obligations and resources of the PFR should be based on the determination of relevant variables and parameters (preferably close to those accepted in world practice), the selection of an appropriate method of tracking the dynamics, and the use of public databases.

\section{EQUILIBRIUM OF A DISTRIBUTIVE PENSION SYSTEM}

When a distributive system is young, the total amount of contributions exceeds the amount of obligations. There are now not many countries where distributive pension systems are young enough and the populations are young enough to generate positive balances. The ideal state of a mature distributive pension system in an aging world would be the equilibrium of the amount of pension contributions and the amount of MPI liabilities.

The functioning of a distributive pension system is determined by many parameters. Among them, the most important are economic and demographic. The main systemic economic parameters (the rate of pension contributions and accrued pension rights) are established by the State, i.e. are prescriptive, but their effectiveness depends on factors external to the MPI system, with market factors prevailing among them.

Demographic parameters and, above all, the age structure of the population are external to the pension system, and at the same time are powerful drivers of the dynamics of MPI. The State has wide possibilities for regulating mortality and immigration, but very limited ones in the area of fertility. The idea of the future of a pension system based only on national programs designed to implement decrees is fraught with multiple and serious deviations of real trajectories from imagined ones.

The State directly regulates pension rights by changing the criteria that a pensioner must satisfy. This may be the retirement age, seniority, insurance record, work at enterprises of certain forms of ownership, the possibility of combining receipt of a pension with economic activity, etc. Although these possibilities of the State seem limitless, in reality they are limited by the social contract expressed in the Constitution and relevant laws, which in Russia declare the universality of the right to a pension and the State's obligation to fulfill this right. The conflict between these factors when carrying out pension reforms exists not only in Russia, and always manifests itself in an acute public reaction to changes in pension rights by the State.

The real possibilities of managing the pension system are also limited by economic factors. Thus, business is sensitive to changes in the rate of pension contributions, which in Russia has changed seven times over the past quarter century. The increases were detrimental to business and caused a decrease in the collectability of contributions, as a result of which they were adjusted. In addition to direct losses, the fluctuations of the contribution rate established by the State negatively affect the investment climate. Therefore, it hardly makes sense to raise its current level in Russia (22\% of the payroll) in order to reduce the deficit of the MPI system's own funds.

However, there is another reserve for increasing total contributions. In Russia, the collectability of pension contributions is very low. In particular, contrary to the law, self-employed citizens generally do not make pension contributions, nor, by definition, do illegal migrants. 
Effective actions to bring these categories of workers out from the tax shadow could, in principle, generate many hundreds of billions of rubles for the MPI's funds.

In Russia, the majority of pensioners have very modest pensions. Although data on the distribution of pensioners by the size of their pensions are not published, the proximity of the average pension to the poverty line points to a large number of extremely low-income pensioners. It is not entirely correct to compare Russian and foreign statistics on the replacement ratio of pensions to wages, due to major differences in methodology, but it would not be far from the truth to assert that in Russia the most simplistic pension replacement rate (33\%) is nearly two times lower than that recommended by international organizations $(60 \%)$ and more than two times lower than that already achieved in a number of countries. The restoration of the high growth rate of pensions which took place in the early 2000s would have made it possible to reach the recommended level of replacement in 10 years, but such a dynamics is utterly unrealistic; officials and researchers formulate much more modest goals (for example, 35\% in 2024). The average size of pensions close to the poverty line and a low replacement rate mean that balancing the pension insurance budget by reducing the size of pensions would be completely unacceptable.

The equilibrium of the system, i.e. equality of resources and obligations, is an ideal, but not a necessary condition for a sustainable MPI. A shortage of MPI funds by itself does not necessarily destroy the system. Covering the deficit, regardless of why it exists, is an unconditional obligation, and not an act of good will of the State. The balancing lever is transfers from the State budget, which in OECD countries provide more than 1/5 of the financial resources of pension systems (Gurvich 2011). Although this is not an optimal situation, the need to fill the deficit of the MPI's own funds using budget revenues is nowhere considered a tragedy. RRAs are usually designed so that the deficit is reduced, but not necessarily completely eliminated.

A system of solidary redistribution of national income to finance the lack of a MPI's own resources is not a fatal aberration of a market economy, but rather a normal tool of a social State, especially adequate to an economy that is largely built on the exploitation of natural resources. In principle, it doesn't matter whether the mandatory insurance fund is financed through a specialized State organization that collects pension "contributions", or directly from the State budget through the same deductions called "taxes". In both cases, the tax base may not be sufficient to balance the MPI budget, but deficits are not supposed to lead to reductions of the State's MPI obligations.

Several analogies might be offered here. For example, the aerospace industry is economically not profitable, but the Russian State does not raise doubts about its necessity. By analogy with pensions, the State is obliged to provide education for citizens of the country. Should the desired rise in fertility occur, in 6-7 years a larger number of children will need schooling. But the right solution would hardly be to increase the age of admission to first grade, followed by a reduction in the duration of compulsory education.

In Russia, in 2008, an additional source of financing the MPI was created - the sovereign National Welfare Fund (NWF), replenished from oil and gas revenues. Like the Norwegian State Pension Fund (Statens Pensjonsfond Utland), the NWF redistributes natural resource rent to finance social development, including a deficit of the pension system's funds. The scale of the need for transfer is great, but the NWF is quite up to the task. 
In this regard, it should be noted that an outright rejection of the acceptability of the growth in the share of pensions in the country's GDP (Kudrin and Gurvich 2012) is not at all obvious. In Russia, MPI payments amount to 7\% of GDP, slightly lower than the OECD average of $8 \%$ and significantly lower than in many countries, including France (14\%) and Germany (10\%). There is no evidence that the high level of State social spending (pensions, healthcare, unemployment benefits) limits the competitiveness of the national economy (De Grauwe and Polan 2003; Yermo 2012).

\section{POPUlation AgING AS JUSTIFICATION FOR INCREASING THE RETIREMENT AGE}

In Russia, all citizens of retirement age have the right to an old-age pension and practically all of them exercise this right. At any given moment the number of such pensioners exceeds the population of retirement age, because many citizens retire before the statutory retirement age. There is no data on the basis of which it would be possible to separately track the dynamics of early retirees. However, since they eventually join the population of retirement age, this phenomenon does not have a big impact on the dynamic series of the number of pensioners. Thus, demography remains by far the major driver of the dynamics of the Russian population of pensioners.

The main factor determining the number of pensioners is their natural reproduction. It should be noted that in Russia, if not $40 \%$ of men died before retirement age, as now, but $5 \%$, as in developed countries, the number of pensioners would be much larger. The process of population aging means higher growth rates of the population of retirement age compared to other age groups - regardless of the definition of its lower boundary. This factor is universal and little susceptible to government intervention. However, in different countries it manifests itself in different ways.

Population aging is caused by low fertility and lower mortality in older ages. Populations age differently and are at different stages of this process. For example, in Russia and the European Union, the growth in the number of elderly people has long outstripped the growth in the total population, but in the second half of the 20th century these dynamics were relatively gentle and attenuated, and in the early decades of the 21 st century growth stopped and will probably not resume again. At the same time, during the same period the number of elderly people grew rapidly in the USA and China, having doubled in the USA (compared to 1950) and nearly tripled in China; and what is more, in the USA the retirement age population will continue to grow for almost a century, while in China, due to the rapid demographic transition, the number of elderly people has already passed the inflection points and will continue to decline (Fig. 1). The gender and age structure of the Russian population is such that in the next 8-10 years the pension burden on the MPI system would decrease even without RRA. 


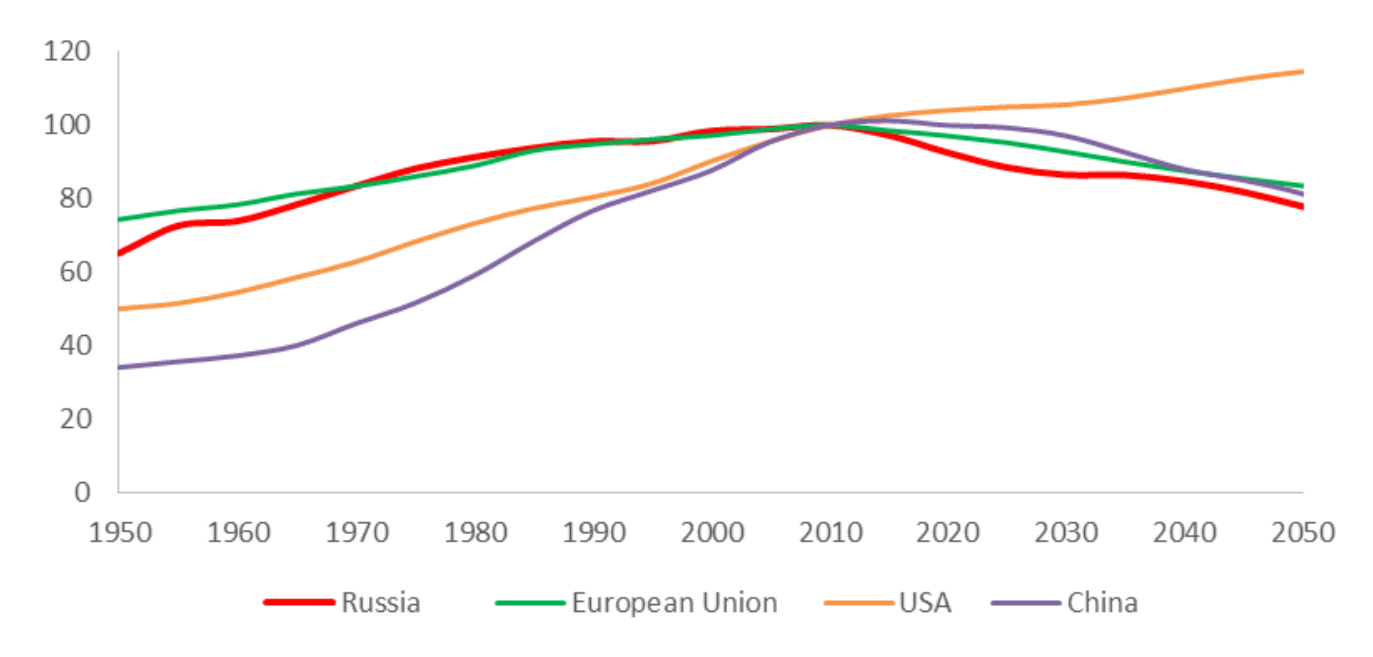

Figure 1. Dynamics of the population aged 60 and over in Russia, the European Union, the USA and China, 1950-2100. $(2010=100)$

\author{
Source: United Nations (2017). World Population Prospects. The 2017 revision
}

In the discussion of pension reform, it is often forgotten that it is the dynamics of the absolute number of pensioners that is the main parameter of the pension system. In particular, these dynamics determine the volume of obligations of a distributive pension system. Consequently, it partially determines the MPI deficit and the need for a transfer from the SWF through the State general budget to cover the pension obligations of the State $^{6}$.

At the same time, in a distributive pension system the balance of receipts and payments is directly related to the most common indicators of population aging - the share of the number of elderly (pensioners) in the entire population (Fig. 2) and the ratio of the population of retirement and working ages. While in the vast majority of countries that have completed the demographic transition, the trends of the elderly population size are currently changing direction, the relative indicators of aging continue to grow. This increase is the main argument in favor of a systematic adjustment of the retirement age.

\footnotetext{
${ }^{6}$ The sometimes used inertial one-factor forecasts of the total population or the size of individual age groups (arithmetic, hyperbolic, logistic, etc.) both at the national and at any administrative level are incorrect. In principle, they lead to false or even absurd results. To analyze the past and predict the future of the pension system, there are accessible, reliable resources posted on the Internet. In Russia, these are the forecasts of the Federal State Statistics Service (Rosstat) and the Institute of Demography of the Higher School of Economics. Supplements and / or alternatives to these resources are databases maintained by the Population Division and the Statistics Division of the United Nations Department of Economic and Social Affairs. The United Nations Population Division's website (https://www.un.org/en/development/desa/population/index.asp) contains several databases, including harmonized demographic estimates and projections for all countries of the world revised every odd year (United Nations 2019). The revisions use both national State official statistics as well as other sources of demographic information. The Division takes into account government replies to questionnaires, feedback from specialized Agencies and Programs of the UN system, other intergovernmental organizations, international and national NGOs, academic institutions and researchers. Relevant issues are regularly discussed at the annual sessions of the United Nations Economic and Social Council Population and Statistical Commissions. All UN Secretariat entities are required to use foremost population estimates and projections compiled by the Population Division.
} 


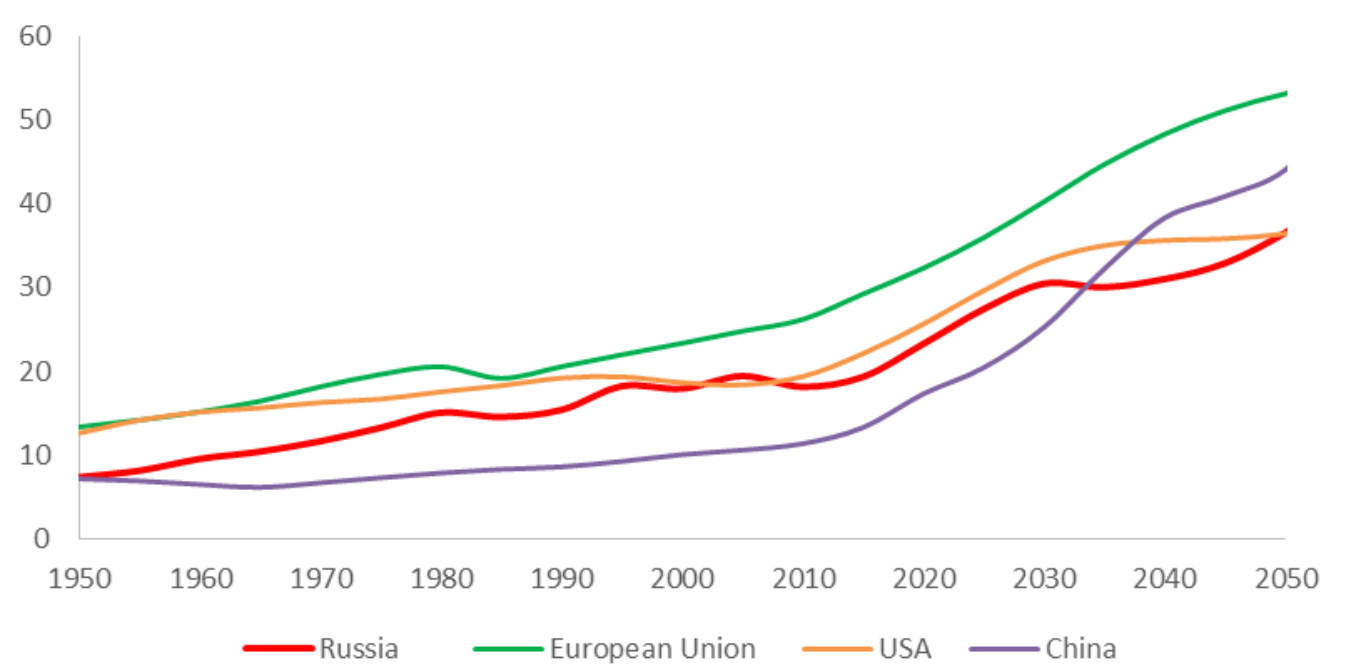

Figure 2. The ratio of the population aged 65 years and older to the population aged 15-64 in Russia, the European Union, the USA and China, 1950-2050, \%

Source: United Nations (2017).

With the same age structure of the population, the number of employed persons varies significantly depending on the levels of economic activity and employment. What matters for the pension system is the number of employed persons (who ultimately pay pension contributions), not that of persons of working age. Meanwhile, in justifying the need for raising the retirement age, the distinction between the demographic burden on the working-age population and the economic burden on the working population, as well as the differences between long-term trends and short-term fluctuations in the age structure, are often ignored (see, for example, A. Kudrin and A. Gurvich 2012). Therefore, often, including in Russia, RRA is presented as a measure with no alternative (Denisenko et al. 2018), and the problem solution cost is conceptualized not as the totality of real costs, but only as the easily observable part of this totality.

Besides, when considering the scale and timing of RRA, it is necessary to take into account not only universal long-term demographic trends, but also their national specificities. Russia differs from other countries not by the fact of aging, but by the shape of the curve describing it. As a rule, aging is a smooth process, but in Russia the curve is so broken that in some intervals aging is not noticeable at all. The seemingly chaotic fluctuations around the uptrend are generated by the demographic echo of the tragic events of the first half of the 20th century, which dramatically deformed the age and sex structure of the population (Fig. 3). In addition, in contrast to Western countries, a decrease in adult mortality played an insignificant role in the aging of the Russian population because over the entire twentieth century this mortality almost did not decrease. 


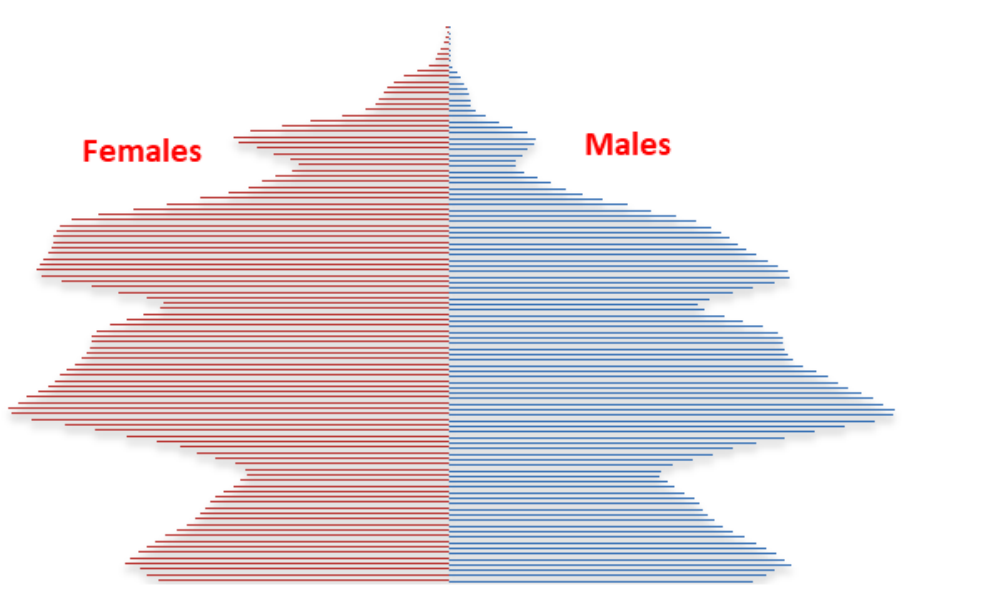

Figure 3. Sex and age structure of the Russian population in 2018

Source: United Nations (2017).

The result of this deformation was the "dancing" dynamics of the retirement age population. The deformations of the age structure are so strong (Fig. 4) that, without taking them into account, a discussion of any "remedial actions" becomes meaningless, since the real effects of an intervention will coincide with the theoretical ones only by chance. In addition, the low retirement age in Russia alone leads to an exaggerated understanding of the extent of aging (GietelBastien et al. 2017).

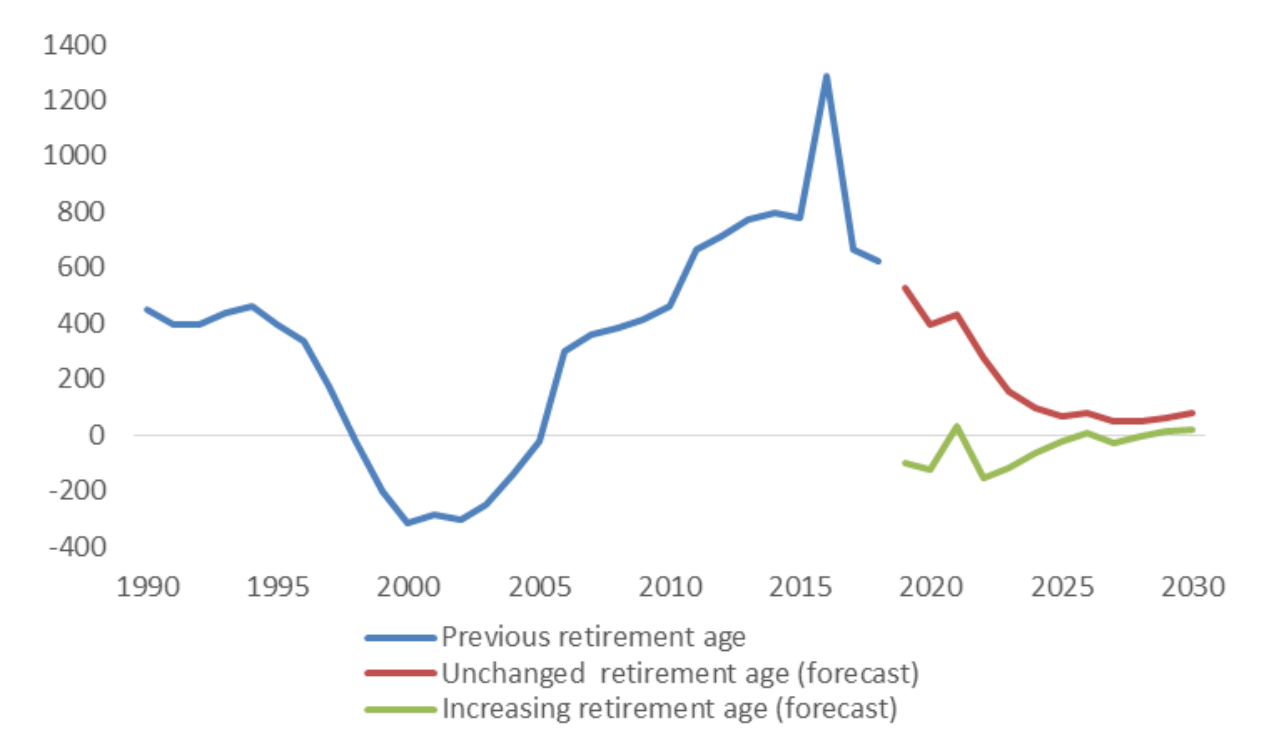

Figure 4. Increments of the retirement age population in Russia in 2000-2030, thousand per year

Source: United Nations (2017).

RRA followed rather than anticipated the rapid acceleration of the growth in the number of pensioners. The peak of growth has passed, and the growth of the retiree population (as defined by previous age criteria) is decreasing as quickly as it had been growing before (Fig. 4); in 2018, it was half that in 2016, and in 2019-23 it will rapidly decrease. After that, the pendulum will swing in the opposite direction, but with a smaller amplitude. Consequently, it is wrong to use rapid population aging as the rationale for urgent and drastic RRA. 
In contrast to the number of pensioners, the number of people employed in the economy, i.e. payers of contributions to the MPI, is determined not only by demographic factors. Not all and not only people of working age work. The reproduction of labor resources is a function of the size of age-gender groups and the levels of economic activity and employment in these groups. Since these economic characteristics vary by sex and age, the age and sex structure of the population affects the total number of employees.

Thus, in terms of economic activity rates (participation in the labor force), men usually surpass women, but not at all ages; people aged 30-60 years are more involved in the labor force than people of older age groups. Yet, many people of retirement age remain in the labor force. The unemployment rate is especially high among young people. These parameters vary in time and space. Although their interrelations with demographic phenomena and processes have been observed (for example, the size of a cohort sometimes affects its position in the labor market), these are weak influences and can be ignored in this context; that is, it is assumed that the economic parameters of labor reproduction are independent from the demographic parameters.

Table 2. Working-age population, labor force and the employed. Russia, 2000-2018

\begin{tabular}{l|c|c|c|c|c|c|c}
\hline & \multicolumn{4}{|c|}{ Number of people, million persons } & \multicolumn{3}{c}{ Average annual growth rate, percent } \\
\cline { 2 - 8 } & 2000 & 2010 & 2017 & 2018 & $2000-2005$ & $2005-2010$ & $2010-2018$ \\
\hline Working-age population* & 87.2 & 87.8 & 83.2 & 83.0 & 0.7 & -0.5 & -0.8 \\
Labor force** & 72.3 & 75.5 & 76.1 & 75.9 & 0.4 & 0.4 & 0.1 \\
Employed & 65.3 & 69.9 & 72.1 & 72.3 & 1.0 & 0.4 & 0.4 \\
\hline
\end{tabular}

Notes: * men aged 16-59 years and women aged 16-55 years; ** economically active persons aged 16 years and older

Sources: Rosstat. Russian Statistical Yearbook; (2002, 2005, 2010, 2018); Rosstat. Labor and employment in Russia (2005, 2017); United Nations (2017).

Labor force participation rates are particularly high in the largest age group - in the working-age population. Therefore, the role of natural reproduction and migration in the dynamics of this age group of employed is especially significant. Wherever fertility remains below replacement level for long periods of time and net immigration does not substitute for it, the growth of the working-age population ultimately becomes negative. In most European countries, this turning point occurred simultaneously, at the turn of the $21^{\text {st }}$ century. The faster was the decline in fertility in the 1960-1990s, the faster is the decline of the working-age population now. In China, the collapse of fertility in the 1970-1980s will cause a sharp decline in the working-age population already in the coming decade. Only in the USA and Australia can and will the working-age population grow for a long time, because fertility in these countries is higher and immigration is greater. For a long time, the Russian trajectory did not differ from the European one, and in 201030 there has been and will continue to be an accelerated reduction in the working-age population ${ }^{7}$.

\footnotetext{
${ }^{7}$ In the Soviet Union, demographic projections were rarely implemented and were classified, but experts knew about Western research. In post-Soviet Russia, not only authoritative research organizations, but also Rosstat the Government Statistical Agency - are engaged in demographic forecasting. So the trend shown in fig. 3 should not be a sudden revelation.
} 


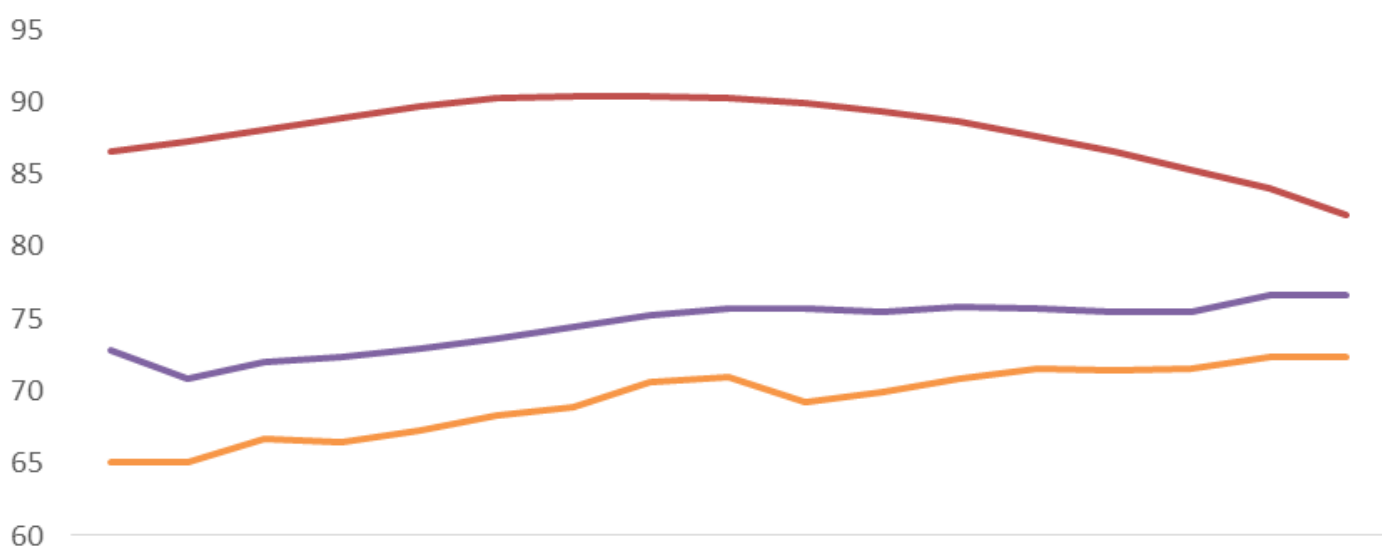

20002001200220032004200520062007200820092010201120122013201420152016

Working-age population Labor force _-Employed population

Figure 5. The working-age population, labor force and employed population. Russia, 2000-2016, million people

Note: The data of the chronological series have flaws: Rosstat often revises estimates and does not explain the reasons in all cases.

Sources: Rosstat. Russian Statistical Yearbook (for different years); Rosstat. Labor and employment in Russia (for different years); United Nations (2017).

A demographically determined rapid decrease in the working-age population ${ }^{8}$ (by 7.3 million people over 6 years) was already taking place in the 2010s. The labor force also decreased, but to a lesser extent (by 2.7 million people). The economic recovery of the first half of the $2010 \mathrm{~s}$ significantly increased the demand for labor, and the ensuing recession caused a reduction in the number of employed. The number of employed in 2010-2014 increased by 860 thousand people, and then over the next two years shrank by 820 thousand. The strength of economic factors was so great that they overcompensated for demographic shifts. The current economic crisis is unfolding against the backdrop of a deep spatial mismatch between the distribution of the workingage population and jobs in the context of the underdeveloped national labor market. As a result, low unemployment (i.e., a low proportion of unemployed people in the labor force) is combined with a low level of economic activity, which suggests that many working-age people do not enter the labor market because they do not believe that an active job search will be crowned with success. While in the developed countries this problem is marginal, in the underdeveloped economies of the South it is pervasive and presents a fundamental obstacle to development. Russia is situated somewhere in between.

However, the dynamics of labor force participation is more nuanced than suggested by the figures cited above. For instance, the number of working pensioners increased from 5.6 million in 2010 to 6.9 million in 2016 . This was partly due to an increase in the number of pensioners, as the

\footnotetext{
${ }^{8}$ The working-age population, according to the definition valid before the pension reform, consisted of men aged 16-59 years and women aged 16-54 years. Employed are those who were employed or who received other labor income during the week preceding the survey. The labor force (economically active population) consists of persons who were employed or unemployed (i.e. did not have a labor income and were actively looking for work) during the same period.
} 
large generations of post-war baby boomers entered retirement age. However, the largest component of the increase in the number of working pensioners in the 2010s was the growth of their economic activity, which was not due to any shift in the retirement age, but occurred "on its own". The reason, apparently, was a low ratio of pensions to wages and a decrease in the real size of pensions.

Thus, there was no generalized linear positive relationship between the demographically determined number of working-age people and the economically determined number of employed people (Fig. 5). Actual trends can even be interpreted as a feedback: a rising level of employment compensates for the decline in the working-age population when the demand for labor is constant. If so, then the market is building a healthy, effective and promising mechanism of adaptation to demographically determined reduction of labor resources. Moreover, it looks like in this area Russia has a relative advantage over developed countries, which will inevitably have to search in the immediate future for an answer to the challenge of aging and depopulation.

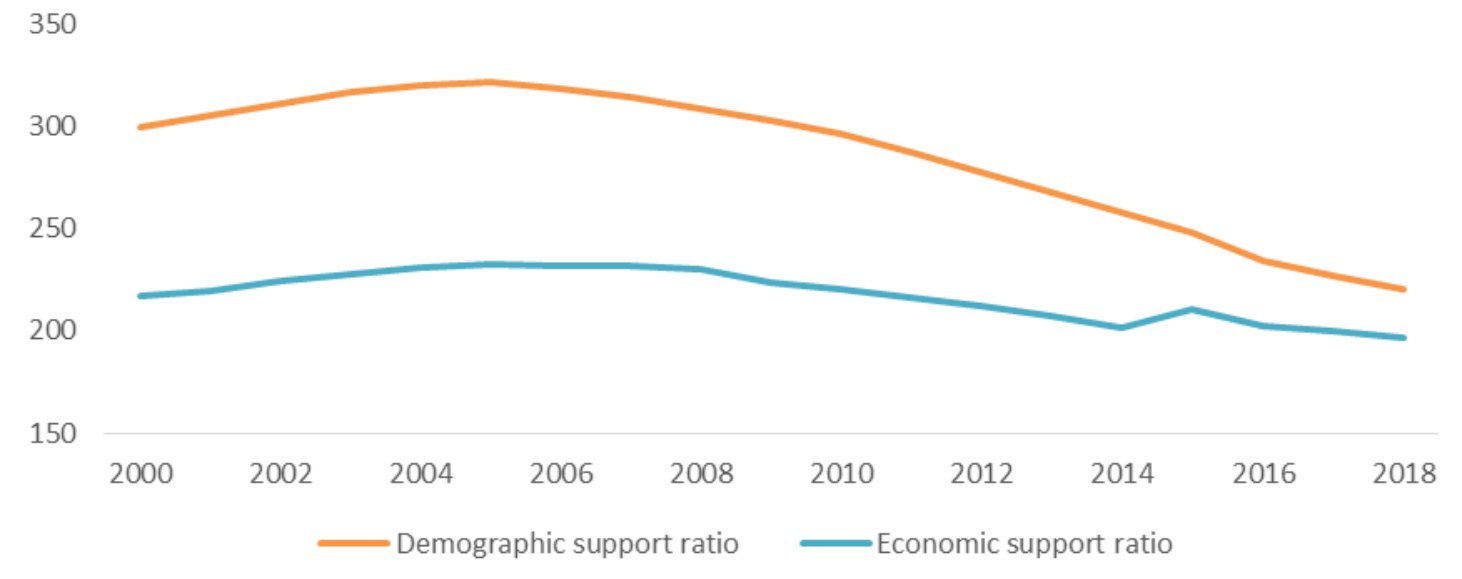

\section{Figure 6. Demographic and economic support ratios in Russia, 2000-2018, number of pensioners per 100 working-age and employed persons}

Note: The data of the chronological series have flaws: Rosstat often revises estimates and does not always explain the reasons

Sources: Rosstat. Russian statistical ... (for different years); Rosstat. Labor and employment in Russia (for different years); United Nations (2017); Model estimates for 2017-18.

The demographic support is inadequate to gauge the ratio of sources to recipients of MPI funds, as having a job does not always correspond to being of working age. The demographic support ratio can be used to predict a smoothed trend in the sustainability of the pension system for many decades to come, but in the range of 10-20 years it is unacceptable, especially with respect to Russia. The forecast for this interval must necessarily include the hypotheses of economic activity and employment, which is a separate task.

The economic support ratio is adequate for retrospective analysis. It shows (Fig. 6) that over the past two decades the ratio of the number of employed to the number of recipients of insurance pensions has not changed uch $^{9}$, while the ratio of the number of people of working age

\footnotetext{
${ }^{9}$ The explanatory note to bill N 489161-7 justifies the RRA by the fact that "the ratio of the number of employed
} 
to those of retirement age (the demographic support ratio) has decreased by $1 / 4$. The economic support ratio does not refute the argument about decreasing the ratio of payers of contributions to recipients of insurance pensions in the long run, but it does show that there is no reason to dramatize the trend.

As the demographic and economic ratios have come close to each other, the demographic projection suggests that the economic support ratio will decline, but the decline will be moderate and will not exceed 20 points by 2030. Of course, if Russia effectively embarks on an intense, i.e. labor-saving, path of economic growth, then the employed population will decline even without a demographic factor. Consequently, the decline in the economic support ratio will accelerate. In this scenario, a decrease in the working-age population will become a favorable factor limiting the growth of unemployment. By analogy with the current redistribution of oil and gas revenues, it is quite natural to channel part of the income thus saved (from modernizing the economy (because of a lesser need for unemployment benefits) into the pension system. All other options for balancing MPI income and expenses (increasing contribution rates, reducing pensions, RRA) are worse on social grounds.

\section{JUSTIFYING AN INCREASE IN RETIREMENT AGE BY A GROWTH IN LIFE EXPECTANCY}

Over the past 10 years, life expectancy at birth has increased by 6 years. By world standards, this seems to be a good result, if one ignores the long-term trend, its gender structure and comparison with the experience of other nations. In fact, the growth of life expectancy in 2007-2017 only compensated for the surge in mortality in the 1990s, when life expectancy was reduced by 4.5 years, plus a modest one-and-a-half-year increment. In Russia, the life expectancy of women at birth is 3 years less than in China and 7 years less than in the European Union. This lag is significant, but for men it is striking - 9 and 13 years, respectively (Fig. 7). When the RRA began in European countries, the life expectancy of men was 5 years longer than now in Russia. Thus, if life expectancy at birth is considered an adequate indicator of readiness for RRA, then Russia is obviously not ready for it. The authorities used the argument that life expectancy should rise to 80 years by 2030. The problem with this argument is that it is not clear why it should or how. Pension reforms usually rely on already achieved demographic parameters, yet both longand short-term past life expectancy trends in Russia call into question such a forecast.

Meanwhile, the indicator of life expectancy at birth is generally not adequate to the task. One cannot, as is sometimes believed, subtract the retirement age from this indicator to obtain the life expectancy in retirement ${ }^{10}$. If this were so, then in Russia in 2000, men who reached 60 years

and pensioners by 2025 will be 1.04 [104 in the dimension used here], while now it is 1.12 [ 112]." This statement is incorrect for three reasons. Firstly, deductions to the MPI are paid (should be paid) by all employed, and not just hired workers. Secondly, the number of pensioners is much larger than the number of pensioners receiving an MPI pension. Thirdly, not all pensioners receive an insurance pension. No matter how you count (with or without correction of the numerator and denominator), the support ratio is almost twice as high as that given in the note.

${ }^{10}$ Russian government agencies systematically stumble over the interpretation of demographic indicators. Thus, the Ministry of Health, and after it the government apparatus and the Presidential Administration mistakenly believe that the number of births shows the fertility level, and that life expectancy and mortality are 
of age would have been characterized by a negative life expectancy, and even now the PFR would not have the problem of financing insurance pensions (i.e. there would be few to receive them), as after slaving in the galleys one would immediately cross the Styx.

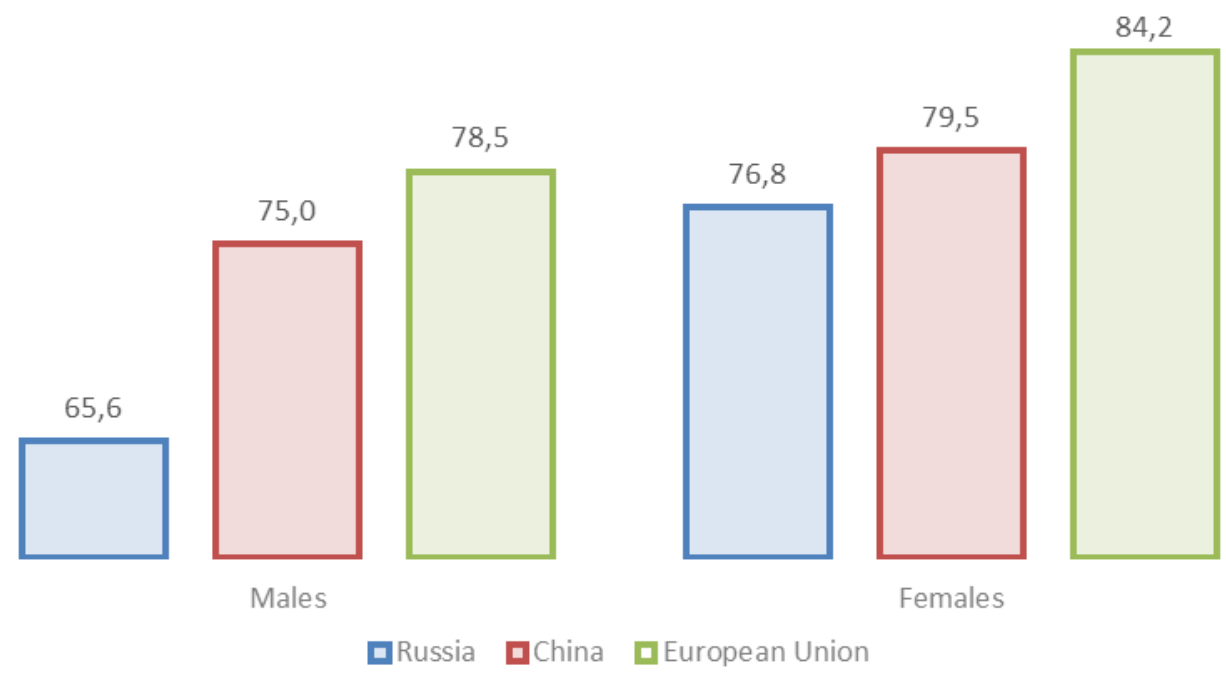

Figure 7. Life expectancy at birth in Russia, China and the European Union in 2015-2020, years

Source: United Nations (2017).

Life expectancy at birth and upon retirement are not linearly related; there is no and cannot be a general formula for the transformation of one indicator into another. Since not only the levels, but also the dynamics of mortality are age-related, the trends in life expectancy at birth and agespecific expectations of remaining life are not parallel. In Russia, this discrepancy is especially large due to the extremely high mortality of working-age men.

Table 2. Life expectancy at age 60 in Russia, the European Union and China, 1950-2020. Average annual levels (years) and growth rates (\% per year)

\begin{tabular}{|c|c|c|c|}
\hline & European Union & China & Russia \\
\hline \multicolumn{4}{|c|}{ Men } \\
\hline \multicolumn{4}{|l|}{ Life expectancy } \\
\hline 1950-1955 & 15.7 & 9.6 & 14.9 \\
\hline 2015-1920 & 22.2 & 18.9 & 15.8 \\
\hline Average annual increase in $1950-2020$ & 0.6 & 1.1 & 0.1 \\
\hline \multicolumn{4}{|c|}{ Women } \\
\hline Life expectancy & & & \\
\hline 1950-55 & 18.4 & 11.7 & 18.8 \\
\hline 2015-20 & 25.3 & 20.7 & 21.0 \\
\hline Average annual increase in $1950-2020$ & 0.5 & 1.0 & 0.2 \\
\hline
\end{tabular}

Source: United Nations (2017).

Thus, the appropriate indicator for measuring mortality of retirees is life expectancy at retirement. Six decades ago, the life expectancy of 60-year-olds in Russia did not differ much from the average European level, and it exceeded the Chinese level by 5 years for men and 7 years for 
women (Table 2). Subsequently, these indicators in the European Union grew by $0.5-0,6 \%$ per year, and in China twice as fast. In Russia, the life expectancy of 60-year-old women increased 2.5 times more slowly than in the European Union, and of 60-year-old men - 6 times more slowly. As a result, in the space of 65 years Europe achieved a 7-year increase in this indicator and China a 9-year increase, while in Russia it increased by only one year for men and 2 years for women. The country lagged behind Europe by 4 years for women and 6 years for men, its lead over China in women's life expectancy disappeared, and for men, a 5-year lead turned into a 3-year lag. This is not a hypothesis that can be challenged, but an observable statistic.

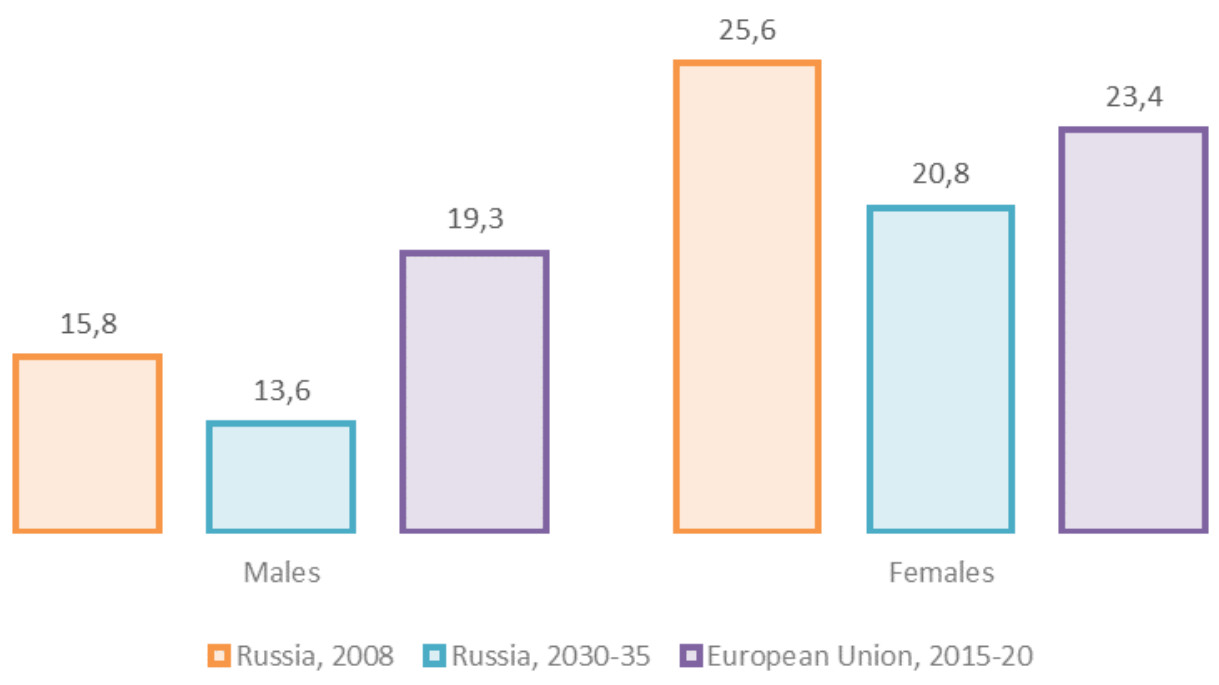

Figure 8. Life expectancy at retirement in Russia and the European Union, years

\begin{abstract}
Notes: Russia, 2018: life expectancy of men aged 60 years, women aged 55 years; Russia, 2030-35: life expectancy of men aged 65 years, women aged 60 years; European Union, 2015-20: the average retirement age in 2017 was 64 years for men and 63 years for women, but the estimates given here relate to life expectancy at 65 years.
\end{abstract}

Source: United Nations (2017).

Assuming a life expectancy in retirement that has been achieved in the West when RRA started to be a criterion of readiness, then Russia does not satisfy it (Ivanov 2016). On the other hand, the decreed 5-year RRA will far exceed the expected increase of life expectancy at retirement ten years from now. As a result, life in retirement will be reduced (Fig. 7), which is unlikely to please citizens, though it is in the interests of the PFR. Even if improvements go as quickly as the Government wants, men's life expectancy in retirement even by 2035 will not have reached the milestone that Western countries had reached when their RRAs began.

Several studies have shown that retirement contributes to better health, while continued work beyond retirement age, on the contrary, leads to its deterioration (Hessel 2016; Blake, Garrouste 2017). This deterioration is especially noticeable for people with inferior education, whose life expectancy is much lower than for people with higher educational levels (at the age of 50 by 4.4 years for women and 3.0 years for men - see Shulgin, Zinkina, Shcherbov 2018). Therefore, RRA is in conflict with the proclaimed goal of rapidly increasing life expectancy. 


\section{SCHEDULE OF INCREASING THE RETIREMENT AGE}

Over the past 10-15 years, the retirement age has been raised in many countries. As in Russia, this is taking place due to continuous shifts jeopardizing the solvency of redistributive pension systems. Usually, States resort to RRA when they realize that serious changes are occurring in the economy and society, and that civil society is sensitive to this issue. The main conclusion, which follows from accumulated experience and does not necessarily need to be confirmed by one's own national experience, is the idea that even a modest increase in RRA will have a serious impact on resource flows.

As a rule, governments preparing a RRA do not try to conceal that such a reform is, in principle, a zero-sum game, and do not pretend that everyone will immediately experience the beneficial effects. They strive to prevent the painful impacts of the reform from crossing the lines of outright rejection by the society and therefore choose a small angle of inclination of the RRA, limiting the scale of the increase, stretching it over time and avoiding jumps - that is, sacrificing a part of the financial gains in order to minimize social risks. This is the decisive qualitative parameter of the reform, a guarantee of its acceptance by society and of its irreversibility. It is so clear to everyone that it is wrong and dangerous to hide one's head in the sand for decades, then try to jump as far as possible in order to immediately begin correcting the consequences of the deed, that such aberrations are not often discussed in the literature.

In the West, the most radical RRA has been carried out in Italy. In 2012, the retirement age for women in the private sector was increased immediately by 2 years to 62 years, and subsequently by 8 months a year until reaching the age of 66 in 2018. Since 2019, a periodic (every two years) linkage of retirement age with life expectancy has been introduced. The technocratic cabinet of M. Monti paid for the reform with the foreseeable resignation and crushing defeat of his party coalition in the parliamentary elections. In France, the increase by the government of N. Sarkozy of the retirement age from 60 to 62 caused the longest nationwide strike in the history of the country, which almost led to a government crisis.

Typically, the retirement age is raised by 2-3 months per year, sometimes with intervals being made between the increments. For example, in the American system of state pension insurance (Social Security), the full retirement age is 65 years for people born before 1938; each annual cohort born in 1938-1942 begins to receive a full pension two months later than the previous one; for generations born in 1943-54, there is a common retirement age of 66 years; for the generations born in 1955-59 the retirement age is increased in two-month increments; and for subsequent generations there is a common retirement age of 67 years. At the same time, there is an unconditional opportunity for everyone to start receiving a pension both ahead of schedule and after retirement age with a corresponding reduction or increase in the size of the pension.

An indispensable condition for a successful RRA is the preliminary study of the whole complex of socio-economic consequences of the reform. It is trivial but fair to emphasize that a thorough public discussion of the reform project by involved departments, experts, the media and NGOs - with the contribution of such experienced international organizations as the IMF, World Bank, ILO, OECD and the European Union - not only ensures the quality of the reform, but also contributes to reaching a national consensus on the basis of a compromise among the interests of different groups. In other words, it is necessary to seek the prior consent of society for reform, and 
for this it is necessary to ensure the financial literacy of the population. Data on legislative elections in 21 countries in the period 1990-2010 show that the financial literacy of the population reduces the electoral price of large pension reforms, while the general educational level of the population does not compensate for the lack of relevant knowledge (Fornero, Lo Prete 2019). Financial literacy not only directly contributes to public understanding of the need for reform and the correctness of the methods proposed by the government, but also pushes the media to a balanced and comprehensive coverage of these issues.

Russia has taken an original path in this matter. It was decided to raise the retirement age by quite a lot, to do it in large annual increases and to start almost immediately after the public announcement of the decision. Even if we assume that the Russian Government correctly formulated the problem, made the correct diagnosis and correctly determined the goals of the pension reform, it turns out that the method of its preparation and the scheme itself are still questionable.

For a decade and a half, the official position in Russia was to refuse RRA from the very outset, although reforms of other aspects of pension provision were carried out. Neither the PFR annual report for 2017, nor the federal budget for 2018, nor the message of the President to the Federal Assembly of 2018, nor his Decree of May 2018 which formulated the strategic objectives for the development of the country contain even a hint of a crisis in the pension system and the need for RRA. Moreover, the President positively assessed the demographic situation in the country. Then, the Government suddenly announced an RRA starting January 1, 2019, limiting discussion of its decision to just a few months. Contrary to statements by the Presidential Administration about negative changes in the demographic situation that have occurred over 15 years, they contained no new revelations in terms of facts and ignored the definitive prediction that population aging will keep slowing down. Concurrently, the Government kept silent about the new and bad economic trends, yet it is repeatedly stated that the implementation of the 2018 State budget ended up in a large surplus. As is increasingly happening on other issues as well, the Government-related media covered the reform from a purely partisan position, neither bothering to check the scattered information nor paying attention to formal contradictions in their own narrative.

Less than 3.5 months after the Government introduced the bill on RRA in the State Duma, it was adopted in the final reading, despite earlier protests from the opposition (which in itself was a unique phenomenon), and its widely publicized mitigation in just one aspect (RRA for women for 5 years instead of the originally proposed 8 years) was accompanied by a significant, but all but unnoticed tightening in another (cutting in half the time between RRA increments). A public opinion poll showed that $85 \%$ of citizens reacted negatively to the RRA legislation (Levada Center 2018).

The explanation for the suddenness may consist in the fact that the problem of the chronic large deficit of the PFR had been ripening for a long time, the government hoped that it would resolve by itself, and since it did not, it was decided to go on a frontal attack and push the reform through before everyone came to their senses - and, what's more, implement the RRA to the maximum. An alternative explanation is that the Government ignored the problem, but something or someone finally opened its eyes to the deplorable situation. The most likely explanation is 
opportunistic. In the early summer of 2018, two negative phenomena intertwined in a tight knot: the windows for overcoming economic stagnation were closed and foreign policy risks aggravated. The authorities, as usual, decided to apply the principle of socialization of costs with the monopolization of benefits. This explanation is consistent with the reluctance not only to recognize, but even to discuss the fact that the trillion ruble increases in the consolidated national budgets due to RRA are not manna from heaven and not a surplus value, but the result of redistributing the national economic pie.

The explanatory note to the pension reform bill of June 16, 2018 unequivocally named the goal of the reform: to eliminate the demographically caused deficit in financing pension insurance. Significantly broader economic and social justifications would gain ground in official explanations and opinions expressed in the media by MPs, Government officials and associated supporters of the reform: to provide the country's economy with labor resources, national projects with financing, pensioners with higher pensions, and senior citizens with better opportunities for selfrealization. Implied, and sometimes openly used, is a civilizational argument: we are not the first, in the West they have been raising the retirement age for a long time, it is time for us to do the same. It is proposed to take on faith the assertion that if the RRA is not raised immediately and to the degree decided on, then inevitable future reform would be even harsher.

\section{THE IMPACT OF INCREASING THE RETIREMENT AGE ON THE DYNAMICS OF THE NUMBER OF PENSIONERS}

The irregularity of the age structure of the population of Russia caused by the Great Patriotic War predetermines the undulating dynamics of the population of retirement age: a seven-year growth period in 1990-1997 was followed by a 7-year decline in 1998-2005, then by 12 years of rapid growth in 2006-2018. Over the next 4 years (2019-2023), annual growth will decrease by almost half, and in 2024-2030 the number of men over 59 years old and women over 54 years old will almost stabilize.

The reform will automatically reduce the number of pensioners. By July 1, 2019, there will be 1.5 million fewer pensioners in the country than on July 1, 2018, and 2 million fewer than there would have been without reform. The number of pensioners in 2034 will be 8.2 million fewer than if the retirement age had not been changed. However, the dynamics will not be monotonic. The RRA will produce the greatest effect at the reform implementation stage, i.e. in 2019-2023: instead of an average annual increase of 357 thousand people, the number of pensioners will be reduced by 1,439 thousand people per year. However, as soon as the reform is completed, the growth in the number of pensioners will resume (Table 3).

Table 3. The average annual change in the number of pensioners, 1950-2034, thousand people

\begin{tabular}{c|c|c}
\hline Period & Constant retirement age & Increasing retirement age \\
\hline $1990-1997$ & 380 & \\
$1998-2005$ & -218 & \\
$2006-2018$ & 632 & \\
$2019-2023$ & 357 & -1439 \\
$2024-2030$ & 68 & 220 \\
\hline
\end{tabular}

Source: United Nations (2017). 


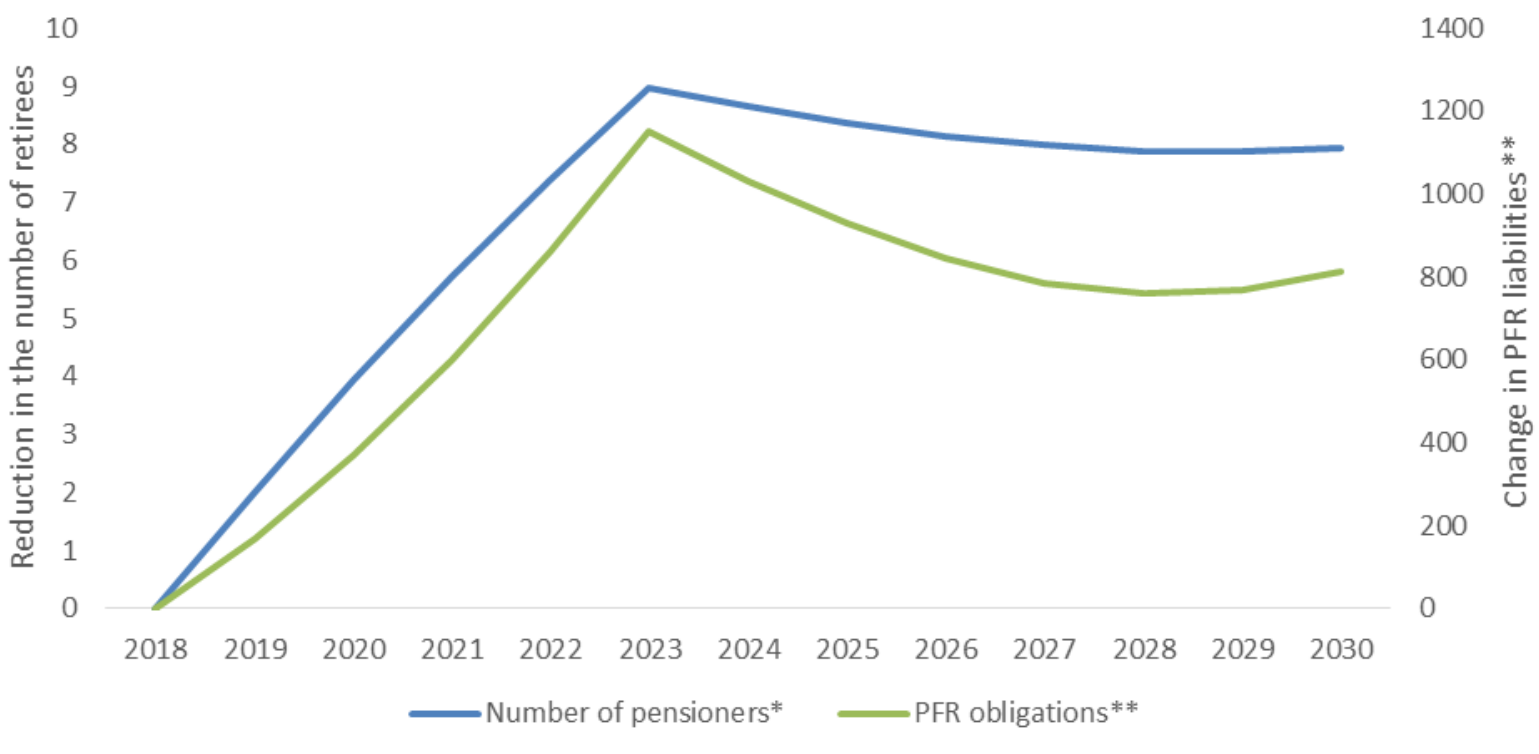

Figure 9. Change in the number of pensioners (million people) and PFR obligations (billion rubles), 2018-2030

\begin{abstract}
Note: * compared with the number of persons of retirement age by its previous definition; ** the difference between the PFR's MPI obligations in the absence of a RRA (while maintaining the inflation adjustment of pensions at 4\% per year) and the total obligations of the PFR in the case of RRA and the fulfillment of the obligation to annually increasing pensions by 1000 rubles.
\end{abstract}

Source: United Nations (2017)

The flip side of the encouraging dynamics in the number of pensioners will be the emergence of a problematic group of people whose retirement was postponed by RRA (the "Contingent") ${ }^{11}$. Social protection of this group of elderly people and their adaptation to new conditions will require significant efforts of the State and society (see below).

\title{
THE FINANCIAL EFFECT OF INCREASING THE RETIREMENT AGE
}

The financial consequences of RRA for the State are determined by the size of the Contingent and a number of economic parameters. The size of the Contingent is set by the demographic trends. The most important economic factor in the balance of funds will be the dynamics of the size of pensions. In principle, the average future pension depends on many factors that are difficult to predict. However, the task is facilitated by the fact that the government has firmly promised to annually increase monthly pensions by 1000 rubles. This will substitute for the indexation of pensions for inflation, which is implicitly confirmed by the official estimate of the size of pensions

\footnotetext{
${ }^{11}$ There is no well-established name for this group of people Various designations would be equally suitable , for instance, "Citizens with a deferred right to retire," "Workers who have postponed their retirement"; "Persons with lost pension income"; "Workers who are denied the right to retire in accordance with legislation in force until January 1, 2019"; "Persons in respect of whom the policyholder has changed the terms of the insurance contract"; "Persons of revised working age"; "Pension reform target group". These terms are accurate enough but cumbersome. The short designations "deprived", "refuseniks", "losers" are too emotional. The word "Contingent" is used below as a short, emotionally and ideologically neutral contextual name for this group, not claiming scientific or legal correctness.
} 
in 2019. Until 2030, the new procedure ensures faster growth of pensions, provided that inflation does not exceed 4\%: by 2024, average pensions will cumulatively increase by 2.3 thousand rubles more than indexation would give, and by 2030 - 3.5 thousand rubles more. However, due to a continuing decrease of the relative weight of the thousand-ruble pension increment, the trajectories of the pension size according to these two formulas (indexation for inflation and constant increment) will intersect beyond the projection horizon. The greater the excess of the actual inflation rate over the planned one (4\% per year), the earlier this intersection will occur. Anyway, an annual thousand-ruble growth of the average pension at four percent inflation will ensure a slow growth in the currently low living standards of pensioners. On the other hand, the new formula would not prevent the ratio of pensions to wages from deteriorating. For example, if the average wage in real terms increases by at least 1\% per year, then starting in 2021 the growth of pensions will lag behind the growth of salaries, which will lead to a decrease in the replacement rate from the current low level of $33 \%$ to $28 \%$ in 2030.

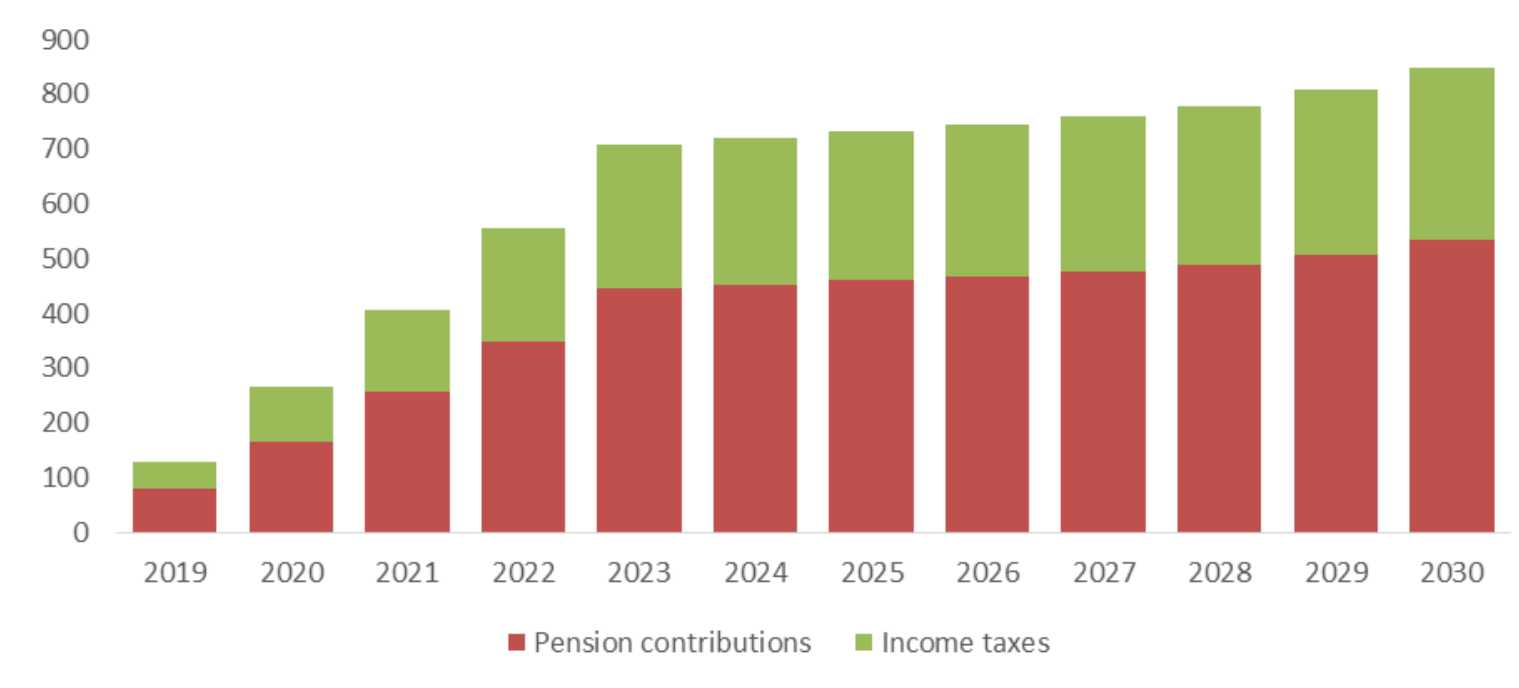

Figure 10. Additional pension contributions and income taxes if $80 \%$ of the Contingent are employed

Note: in 2016, 39.4\% of men aged 60-64 years and 52.4\% of women aged 55-59 years were employed. The number of people employed in the Contingent is calculated as the product of the size of the Contingent and the additions of these values to 80\%. The average salary in 2018 (the first half of the year) amounted to 42,550 rubles. It is assumed that the nominal salary in 2019-30 will grow by 5\% per year.

Calculated by: United Nations (2017); Rosstat (https://regnum.ru/news/2459352.html).

RRA will save money for the PFR due to the reduction in the number of pensioners, even if the PFR fulfills its promise to annually increase pensions by an average of 1000 rubles. In 2019, the amount of savings will be about 170 billion rubles, and for the period 2019-2030 the cumulative decrease in PFR obligations will amount to more than 9 trillion rubles, but only marginally if the additional accumulated outlays for underwriting the promise to keep pensions increasing faster than inflation are deducted. Along with the dynamics of pensions, the financial consequences of RRA for the PFR (as well as for the State budget) will be determined by the Contingent's employment, as employers make contributions to the MPI, while employees pay income tax. 
The following calculation is based on the assumption that $80 \%$ of the Contingent will work ${ }^{12}$, receiving the national average wage which will grow by $5 \%$ per year (in nominal terms), i.e. will reach 57 thousand rubles in 2024 and 76 thousand rubles in 2030. If it proves feasible to keep employment of the Contingent at 80\%, over the period of 2019-2030 the PRF will receive an additional 4.7 trillion rubles of pension contributions, and the State budget will receive 2.8 trillion rubles of income taxes (Fig. 10). Thus, the State's total net revenue from RRA for 12 years would reach 5.2 trillion rubles.

It should be borne in mind that the hypothesis of a very high employment of the Contingent is unlikely (see below). One uncreated job will cost the State more than 200 thousand rubles a year in lost revenue from taxes, pension contributions and expenses for unemployment benefits. In case no additional jobs are created, the reform will produce a net accumulated loss of 3 billion rubles. Thus, the fate of the reform directly depends on success in ensuring the employment of the Contingent.

\section{THE INFLUENCE OF INCREASING THE RETIREMENT AGE ON THE LABOR MARKET}

On January 1, 2019, the dynamics of the working-age population changed radically. By 2030, it will increase by 5.4 million people and reach 81.4 million people, while maintaining the current retirement age would have led to a decrease of 5.4 million people. Linear interpolation between 2018 and 2030 yields an average annual growth rate of $0.4 \%$ as a result of RRA versus a mirror negative average annual growth rate without RRA. However, the true growth trajectory is a broken line, since the rapid growth of the working-age population in 2019-2023 will be replaced by its almost equally rapid decline in 2024-2030. In 2023, the last one-year increase in the retirement age will take place, and subsequently the aging of the population will take over.

To prevent a spike and subsequent more gradual increase in unemployment, the demand for labor should keep pace with the dynamics of its supply. In 2010-2016 the Russian economy created three million ( $\pm 200-400$ thousand) new jobs per year (as reported by official statistics). In pre-crisis 2014, 3.8 million new jobs were created; even in the recession of 2015-2016, 2.9 million were added [Labor and employment ... 2017]. Against the backdrop of these figures, 0.60.7 million additional jobs a year ("earmarked" for the Contingent) seems to be an ambitious yet achievable goal provided a steady economic growth is maintained.

However, the optimistic obverse of the coin has a sobering reverse. Every year, millions of jobs disappear, and sometimes even in years of economic growth more jobs are eliminated than are created. So far, the negative balance of job dynamics has been offset by a demographicallydriven reduction of the working-age population. The rapid increase in the working-age population in 2019-2024, on the contrary, will compound the negative effects of the economy-driven contractions of employment leading to increasing unemployment. Only rapid economic growth within the framework of an extensive development model could generate jobs in the quantities

\footnotetext{
12 This is a super-optimistic assumption. For more information on the prospects of employment for the Contingent, see below.
} 
necessary to absorb the rapid growth of labor resources generated by the RRA. Meanwhile, economic growth even according to the upper versions of medium-term forecasts (including official ones) cannot be called rapid. In addition, the Government wants to switch to an intensive, i.e. labor-saving, model of economic development.

An equally serious issue is the harmony (or rather the lack thereof) of structural characteristics of the labor force with the needs of employers. There is market demand not for just any labor, but for labor with industry-specific qualifications, geographic location and often particular demographic characteristics. In the situation created by RRA, the qualitative characteristics of prospective workers are fundamental. It is implicitly assumed that the increase in the labor force will be met not by absorbing young people into the labor market, as is usually the case, but by keeping senior citizens in it one way or another. It is difficult to measure the degree of disparity of their human capital with the needs of the current Russian economy (let alone a dreamt technological breakthrough), but it would not be an exaggeration to say that young workers are more fully in line than seniors with both the modernizing and the extensive economies.

One of the many aspects of this issue is related to the gender and age structure of the working-age population. As a result of the RRA, the share of men and women aged 40 years and older in the working-age population will increase by 9 percentage points by 2030 versus 6 percentage points in the case of an unchanged retirement age (table. 4). High male mortality combined with RRA will exacerbate the feminization of the workforce. The number of women 3955 years old will increase by 1.7 million by 2030, and the reform will add another 6 million older women to the working-age population. As a result, the proportion of older women in the workingage population will increase from $18 \%$ to $30 \%$. To the extent that labor demand has gender and age preferences, these shifts will require either adaptation of the economy's structure or correction of employers' requirements for labor. If neither happens, a massive increase in unemployment is inevitable.

Table 4. The percentage of men and women 40 years and older in the working-age population, in percent, Russia, 2018, 2024 and 2030

\begin{tabular}{l|l|r|r|r}
\hline & & 2018 & 2024 & 2030 \\
\hline \multirow{2}{*}{ Men } & Constant retirement age & 22.5 & 23.5 & 26.1 \\
\multirow{2}{*}{ Women } & Increasing retirement age & 22.5 & 26.8 & 30.1 \\
& Constant retirement age & 18.3 & 20.5 & 22.3 \\
& Increasing retirement age & 18.3 & 23.7 & 29.7 \\
\hline
\end{tabular}

Source: United Nations (2017).

In the context of economic stagnation or timid growth, a radical, realistic, albeit partial solution to the problem of Contingent employment can only consist in a discontinuation of labor immigration coupled with the expulsion of all labor migrants from the country. It may seem that such a step is more difficult to implement than RRA, but in this domain law enforcement is more powerful than the relevant Government agencies. The predominantly temporary nature of labor migration into Russia facilitates the task. Indeed, one just has to stop issuing and renewing residence and work permits, revoke valid permits, increase penalties on employers for hiring illegal migrants and on landlords for renting them housing, and deport illegal migrants. Current legislation makes provisions for most of these measures, but their implementation is far from systemic. Applying them across the board and strengthening the built-in deterrents may lead to a 
quick drying up of new immigration flows followed by a gradual decline of the number of foreigners in the country. Indeed, this is the exposition of one of several logical responses to challenges caused by RRA rather than an advocacy against immigration.

The logical goal may consist in replacing migrants by the Contingent in construction, agriculture, transportation and services, where foreign labor is used most. At the same time, most members of the Contingent, finding themselves in a precarious situation, would be unlikely to demand higher salaries and better working conditions than migrant workers routinely accept. In particular, this means that people of advanced age will have to agree to work 55-60, or even more than 70 hours a week (Tyuryukanova 2008). An alternative, in principle, could be hiring, to perform the same amount of work, 15 or more employees from the Contingent (with a higher salary) instead of 10 laid-off guest workers, which won't be an attractive solution for employers. On the other hand, if members of the Contingent do not want to work 10 hours a day, 6-7 days a week, they will have to accept a still lower salary.

In order to ensure the harmonization of demand for and supply of labor, it will be necessary to organize the relocation and resettlement of large masses of Contingent members. In addition, it will be necessary to organize the retraining of seniors. The price of such a national program would consume a large, if not most, of the additional pension contributions and income taxes. One could, of course, shift these efforts to the members of the Contingent themselves, but this would further significantly worsen their financial situation, not to mention create new health risks and emotional costs.

The aforementioned issues make the replacement of migrants by the Contingent a project that can only be initiated with forceful administrative methods rather than by market mechanisms, while intentionally ignoring its various negative consequences. However, even the most stringent and expensive methods will not guarantee success. In addition, even if it were possible to completely replace labor migrants with the Contingent, this would solve the problem of their employment only partially, because the number of labor migrants in the country does not seem to exceed 3.5 million people, and net migration does not typically exceed about 300 thousand people a year, while in 2019 alone 670 thousand jobs would have to be created for the Contingent, and this number will grow. In addition, this method of suppressing the effects of the pension reform would in principle be contrary to its main task, since temporary foreign workers pay pension contributions while only rarely claiming pension benefits.

Recognizing the incorrectness of its original premise that RRA was problem-free, the State decided to protect the Contingent by introducing in the Criminal Code ${ }^{13}$ a rule of the Labor Code prohibiting age discrimination and explicitly forbidding layoffs of workers of "pre-pension age".

\footnotetext{
${ }^{13}$ A new article 144.1 of the Criminal Code adopted by the State Duma in September 2019 reads: "Unreasonable refusal to hire a person on the grounds of reaching pre-retirement age, as well as unjustified dismissal from work of such a person for the same reasons, shall be punishable by a fine of up to two hundred thousand rubles or in the amount of the wage or other income of the convicted person for a period of up to eighteen months or by compulsory labor for a period of up to three hundred and sixty hours. For the purposes of this article, pre-retirement age means an age period of up to five years preceding the appointment of an old-age insurance pension in accordance with the pension legislation of the Russian Federation." It is characteristic that punishment for violating the law is a fine benefiting the State, and not compensation for the citizen illegally dismissed or not hired. Moreover, the law has no provisions for a court to force an employer to reinstate or hire this person.
} 
The new article does not please employers and impedes the normal functioning of the labor market. At the same time, it is easy to carry it out formally while sabotaging its purpose: it is enough to indicate another, legitimate reason for dismissal, something which employers usually do already in response to the long-established general prohibition of age-based discrimination. In many cases, this behavior of employers is economically justified by the desire to increase labor productivity by hiring younger staff. In individual cases, it is quite safe to do this, but mass layoffs may attract the interest of supervisory authorities. Para-state corporations and state organizations, threatened by eventual criminal prosecution (although it is not clear just who may be prosecuted), will feel compelled to obey the new prohibition, while begging endlessly for (and receiving) delays and exclusions. Most large private enterprises will sabotage it, because the punishment is less burdensome than losses incurred from following the law. For small entrepreneurs, the ban is almost as absurd as it is for the self-employed. That leaves medium-sized businesses, which already fall victim to all sorts of Government interference. But here as well, the effectiveness of intimidation should not be exaggerated. It is no coincidence that for over six months after the new criminal law was passed there was not a single case (publicized in the media) of its application, although real discrimination of "pre-pensioners" (persons who have five years or less left before reaching the pensionable age) undoubtedly exists. The new conditions may even aggravate "agism" in relation to employees and job seekers who are significantly younger than the retirement age (Klepikova and Kolosnitsyna 2017).

In case the new law is enforced, employers will have two options: not to dismiss the employee until he reaches the new retirement age, while continuing to hire young employees, or to stop hiring younger employees. The first option entails inflating the enterprise's payroll and decreasing the overall staff productivity. The second option may become even more an impediment for the enterprise's development. On a countrywide scale, doubling the number of unemployed citizens under the age of 30 would yield enough jobs to absorb the 2019 Contingent. It is clear that for the entrepreneurs this will result in economic losses, and for society, social problems.

The best option would be to expand the need for labor. So that the Contingent does not take away jobs from other economically active citizens, it is necessary to create these jobs in addition to the usual "old" new jobs. It will not be easy to force the economy to diligently carry out the "demographic task" caused not by the natural reproduction of the working-age population, but by man-made interference in this process. The Contingent has only one advantage over other potential sources of labor supply, consisting of unemployed youth, unemployed women with young children and prospective immigrants. This advantage lies in its members' greater experience in an already acquired profession. For all other relevant parameters (level of education, health, vertical, interindustry and territorial mobility), the Contingent is inferior to younger groups. Thus, it is necessary either to tailor the extensive economic model only to the "old" industries, making their technological renovation unnecessary and unprofitable, or to make the growth in the demand for labor outstrip the possibilities of satisfying it from other sources. In the current Russian environment, both options require a pace of economic growth that far exceeds the Chinese one.

In order for additional new jobs to support the Contingent's employment, it is necessary that they be created precisely for this purpose. In the absence of a mechanism that deprives other groups of workers of the opportunity to get these jobs, members of the Contingent will be left 
without work. On the other hand, it will be necessary to prevent the continuation of work after reaching retirement age. This, in turn, will lead to a reduction (compared with the pre-reform period) of employment of pensioners and, consequently, to a decrease in the economic support ratio. Once again, an even more serious problem is the need to create a national retraining system for millions of people.

For example, in 20191.6 million men born in 1959 and women born in 1964 turned 60 and 55 years old, respectively, thus becoming the first cohort of the Contingent. Let's assume that $80 \%$ of this cohort needs jobs (as opposed to 39\% and 54\%, respectively, as historically observed): this is the level of economic activity of 60-64-year-old men in Japan. In order to provide work for these people, it will be necessary to lay off one-third of the two million employees born in 19541958 or somehow distribute this quota among other, younger generations. In 2020, this cohort will attain the retirement age and will have to relinquish their jobs. If they do not, in 2020 it will be necessary to take approximately as many additional new jobs from elsewhere. But in any case, it will be necessary to increase the number of jobs by another 600-700 thousand to take up the replenishment of the Contingent created by raising the retirement age by one more year. And so on every year. Even if it had been possible to create an appropriate mechanism (which is unlikely), the obstacles created by it would outweigh its advantages.

Moreover, setting the national goal of creating that number of additional jobs for the Contingent would be insufficient to balance the supply of and demand for labor, since people don't just work, they work in certain geographical places and specific industries and in particular enterprises according to specific staffing tables. Hence, it becomes necessary to organize decentralized planning followed by centralized integration of plans and their timely implementation. It is clear that the market, in principle, cannot do this, no matter what signals the Government sends to it. Therefore, to organize such an unprecedented process a considerable administrative apparatus is needed. But even the smooth operation of such an apparatus is no guarantee of success in carrying out a task that is not inferior in complexity to optimizing the functioning of the socialist economy - a task the Soviet Union's command economy never quite managed.

It cannot be said that the State intends not to participate at all in covering the costs of RRA. The Government plans to allocate about 5 billion rubles a year $(1.5 \%$ of the minimum estimated savings of PFR or 4-5 thousand rubles per person in the Contingent) for a new advanced training program for working citizens of pre-retirement age. Little is known about the program itself. So, it is not clear whether this refers to continuing education in a previous profession or retraining for another job. For example, it is not clear how the transition from an unskilled occupation to a trained driver (a profession currently in high demand) will be organized, or whether it would make sense to retrain teachers as medical workers, and office workers as janitors. There is no indication of whether workers themselves will have a choice in the matter. It has not been announced how and where the training will be organized, how long it will last, whether the entire Contingent will be immediately covered by retraining or if selection criteria (closeness to the source of funding, availability of instructors or urgency of need) will be applied. Employers and future students will be interested in being informed whether full-time education is expected and, if so, who is supposed to pay for the missed working days and eventual per diem. It would be helpful to immediately determine the status of the diploma: whether it will give the right to work in the acquired 
profession, the obligation to fill a vacancy or the guarantee of employment. So far there is no word how this program has begun to work. In any case, the overwhelming majority of the male cohort of 1959 and the female cohort of 1964 are unlikely to be enrolled in the program.

\section{SENIORS WITHOUT INCOME}

The most urgent problem is to provide the means of subsistence to members of the Contingent who will lose their pensions while not being able to secure a job. If compensation payment is not introduced to all unemployed members of the Contingent, the RRA will certainly create a group of elderly people who are deprived of any means of livelihood - both because not all members of the Contingent are able to work, and because many working-age people will not be able to find work due to lack of demand for labor. In order to mitigate the social consequences of the reform, the duration of the unemployment benefit should be extended until reaching retirement age. The benefits should be increased. However, the more they approach the deferred pension, the less sense the reform makes. In any case, the social composition of older age groups will change.

Currently, 4 out of 10 citizens of age groups 55-59 years (women) and 60-64 years (men) have two sources of income - pensions and wages, and the remaining 6 are nonworking pensioners. Let's assume that it is not possible to increase the employment rate in the Contingent compared to this level. Then there will be no more opportunities to work in retirement (see above), but a group of older people will appear who are deprived of the sources of an earned livelihood (Fig. 11). If the State doesn't come to the rescue, there will remain three possibilities of material support: family, charity or none.

A decision has been made to pay increased unemployment benefits to unemployed persons of pre-retirement age for a maximum of two years continuously. The size of this benefit (11 thousand rubles) is greater than the maximum unemployment benefit ${ }^{14}$, but significantly less than the average pension. Such a cushion will significantly soften the impact of RRA at first, but the longer the RRA continues, the less this effect will be. Indeed, men born in 1959 will be able to receive this benefit for the entire duration of their stay in the Contingent (one year), while men born in 1964 - for $4 / 5$ of the period for which pensions will be deferred compared to the former law. The costs of these benefits in the first year of the reform will be between 96 billion (should the Contingent achieve maximum employment) and 156 billion rubles (if none in the Contingent finds a job). Extending the period for receiving the unemployment benefit and/or increasing its size will improve the living conditions of the Contingent, while at the same time increasing the cost of the reform to the point the RRA becomes pointless. Besides, the psychological difference between receiving an earned income (wage or pension) and living on the State's largess should not be ignored.

\footnotetext{
${ }^{14}$ The reverse discrimination resulting from this measure is contrary to the spirit of labor law. You should at least choose a different name for these payments.
} 


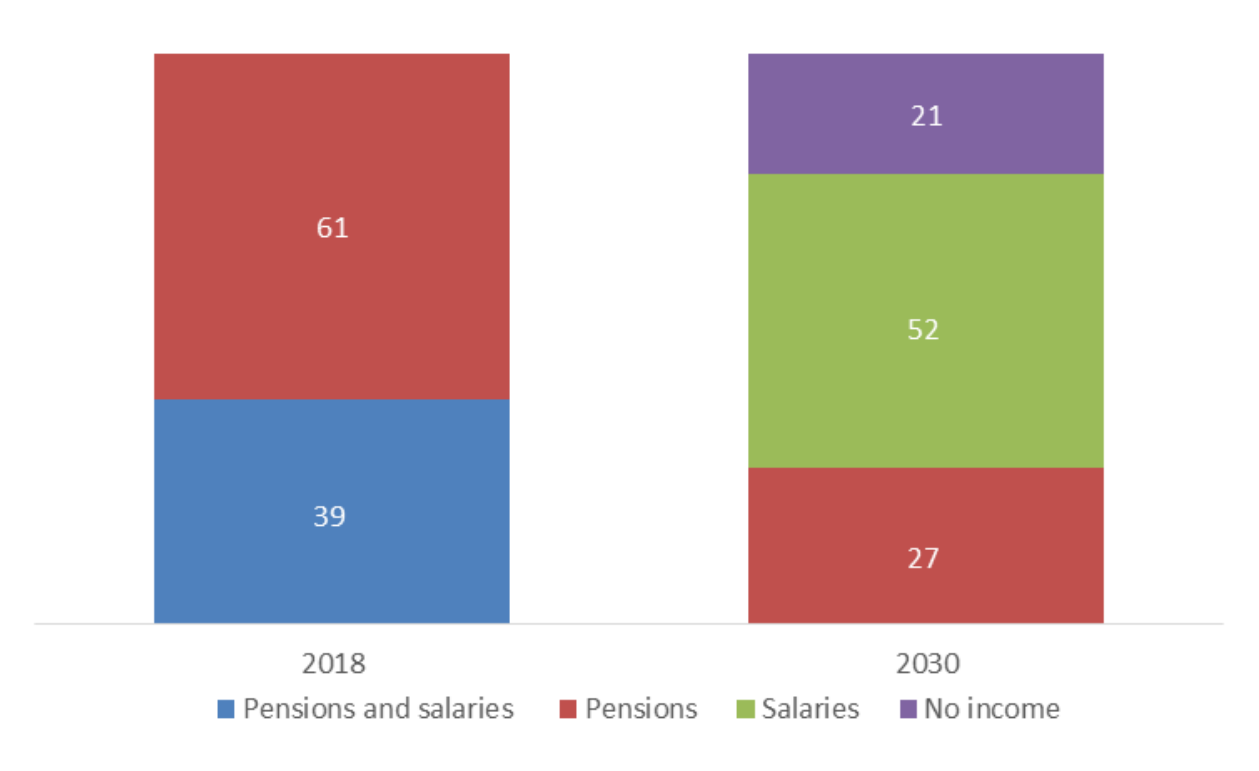

Figure 11. Distribution of men aged 60-64 years and women aged 55-59 years by income sources (unemployment benefits not included), 2018 and 2030

Sources: Rosstat. Social status and standard of living ... (2016); United Nations (2017).

Since the reform is conceived so that the average income in the Contingent cannot but decline, the role of family support, i.e. of spouse, children and grandchildren, should increase. For seniors who are left without their own income, there will be no other source of livelihood at all. Enthusiastic believers in Russia's special way of life will have reason to admire the impulse to strengthen the "traditional family". It is not very clear on what grounds such a hope is based besides the presumption of familial duty. One has to reckon that the number of potential helpers is less than the number of senior citizens who will need income to replace the old-age pension or supplement the "old-age" unemployment benefit. Among people of this age - especially women - there is a high proportion of those who are single and a small proportion of those who are married to someone younger and therefore able to earn a living. It can hardly be expected that all adult children will enthusiastically not only provide some material support for their elderly parents, but assume it fully. Those who do can expect a significant decline in living standards. Aside from unproven assumptions of the inviolability of family values and traditional respect for the seniors, there is no reason to believe that in Russia such support will become as widespread as the intergenerational transfers characteristic of East Asian societies.

Fig. 12 presents two options for forecasting the number of the most disadvantaged unemployed - part of the Contingent. The pessimistic scenario is based on the assumption that RRA will not affect the employment of men aged 60-64 years (it will remain at the level of 39.4\%) and women aged 55-59 years (52.4\%). The optimistic scenario is based on the hypothesis that employment in the Contingent will be raised to a maximum of $80 \%$. The choice of this hypothetical level is due to several considerations. Firstly, at the age of $55-59,80 \%$ of men are economically active, and at the age of $50-54,86 \%$ of women, i.e. this hypothesis is fully consistent with confidence in a problem-free RRA. Secondly, 80\% of Japanese of either sex 60-64 years old are economically active, and this is the highest rate among large developed countries. It is assumed that there will be no unemployment in the economically active part of the contingent. Thirdly, it's quite unlikely that this level can be exceeded. Three-quarters of Russians attain the former 
retirement ages in good or satisfactory health compared to 90\% in Western Europe (Andreev, McKee, Shkolnikov 2003). With such indicators, an 80\% economic activity rate means that $10-$ $15 \%$ of the Contingent will actively seek work despite being in poor health.

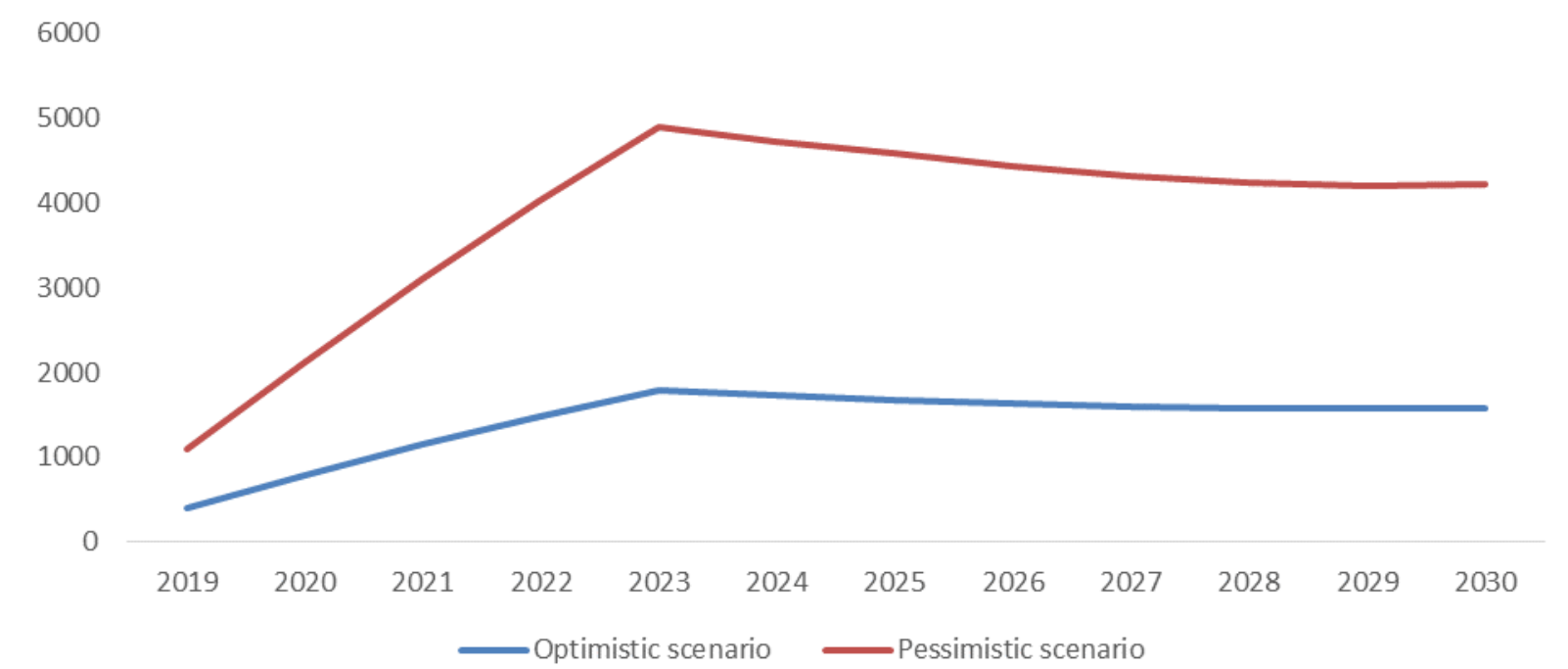

Figure 12. Contingent members with no pension or job, Russia, 2019-2030, thousand people

Sources: Rosstat Russian Statistical ... (2018); Rosstat. Labor force, labor and unemployment ... (2018); United Nations (2017).

It is clear that even those Contingent members who remain employed have little to gain from RRA. Fairly often a person plans his life and then, when something beyond their control interferes with those plans, they are understandably annoyed, especially when they were planning for just a few years ahead. RRA forces everyone with life plans to change them. Moreover, it is unlikely that, aside from a rather small minority for whom postponing the right to retirement will make it possible to fulfill a pre-existing desire to work longer, people would applaud the reform. It happens (in the West often, in Russia, probably rarely) that a person dreams of retirement because this will allow him to start a new career in another field. In the new conditions, the possibilities for this may be reduced. Parents of young children will not be able to count on the help of those grandparents who were asked to stay at work. This will affect the timing of fertility and is unlikely to give it the boost which the Russian State cares so much about.

The availability of work is not a characteristic of, but a prerequisite for material well-being. Also important are the level of income and the volume of other material goods associated with the social status of a pensioner which are foregone for the Contingent. If the Government fulfills its promise, then each member of the Contingent, upon reaching retirement age, will receive a larger pension than if the retirement age had not been raised ${ }^{15}$. The individual average gain from the reform can be estimated by comparing the amount of accrued (over a lifetime ${ }^{16}$ ) pension lost as a

\footnotetext{
${ }^{15}$ A frequently used comparison of pensions annually growing by 1,000 rubles per month with a permanent pension is incorrect, since, according to legislation in force until 2019, pensions should be indexed by the inflation rate of the previous year.

${ }^{16}$ The calculation refers to generations of men and women who reach the retirement age in 2024. Remaining life expectancy for men in 2020-2024 will be 16.0 years at the age of 60 years and 13.2 years at the age of 65 years. The
} 
result of the RRA (adjusted for inflation) with the amount of accumulated pension increasing annually by 1000 rubles per month. It turns out that RRA leads to a significant net volume of lost income: 1 million rubles for men $(21 \%)$ and 1.2 million rubles for women (12\%). In the years 2020-23 the growth of the average pension according to the new formula will be approximately twice the growth guaranteed by the old legislation, assuming a $4 \%$ inflation rate. Each year the gap will decrease, and in the 2030s will become negative. The calculation does not take into account the loss of numerous significant benefits provided to pensioners in Russia, including but not limited to preferential tariffs on utilities, reduced real estate and real estate transaction taxes, preferential tariffs on public transportation, health and sanatorium services.

Considering from a cohort (as opposed to a calendar) perspective the shifts due to the RRA in the balance of pension contributions and pensions accrued during a lifetime, it turns out that at the former retirement age men contributed twice the amount of benefits they received while women contributed slightly less than they received. A 5-year increase in the retirement age, provided life expectancy increases as projected, will change these ratios in favor of the MPI system: slightly for men (from 2.0 to 2.1 ) and significantly for women (from 0.95 to 1.3 ).

\section{INTERNAL RESERVES OF THE REDISTRIBUTIVE PENSION SYSTEM}

Raising the retirement age will immediately and greatly replenish the State treasury. The social price of additional revenues of the consolidated State budget will be high, and some problems are unlikely to be resolved. Considering the existence of the problem of financing the MPI and the demographically predetermined aggravation of it in the long (but not medium) term, the question arises of alternative ways to solve it. The leitmotif of the official discourse is the assertion that such alternatives do not exist. This statement is far from the truth. There are many alternatives at all levels of determination of the flows of resources into the pension system.

It is hard to believe that in the PFR - an organization with a budget of 1/10 of the country's GDP - there are no internal reserves, especially since there has been no attempt to identify such reserves (at least the public is not aware of such actions). The lack of necessary information makes us refrain from quantitative speculation on this topic.

The provision of distributive pensions can be much better adapted to an aging population than raising the retirement age. The general direction should consist in equalizing pension rights. To do this, it is necessary to homogenize pension benefits and eligibility criteria for numerous occupational and otherwise defined groups. In recent years, the prevalence of occupational illnesses has been declining, while working conditions in hazardous professions, as well as environmental standards in at least selected heavily polluted cities, have been improving. Yet instead of gradually deconstructing the system of pension preferences and special benefits, including early retirement age, the State not only maintains them, but even enhances some.

A separate and potentially more promising issue is the need to improve the collection of contributions to the MPI. At present, the legal obligation to pay contributions to the pension

life expectancy of women will be 26.6 years at the age of 55 years and 22.4 years at the age of 60 years. 
system, irrespective of the form of ownership, type of employment and the status of the employer, is not fully implemented for numerous categories of workers, and the number of workers evading this obligation runs into the millions or perhaps even tens of millions. This is not an innate incurable defect of the MPI: in most developed countries, it has been possible to maximize the collection of contributions to national MPI systems. The PFR could begin to solve this problem, but judging by its annual reports, the Fund considers it to be no longer on the agenda.

\section{FUNDED PENSIONS}

It is generally recognized that funded pensions should be a strategic way of developing a pension system because they overcome its dependence on population age structure and turn pension contributions into an economic resource. By its nature, the funded system does not depend on the age structure, but strongly depends on the quality of management of financial instruments. However, it is believed that the funded component should be considered - at least during the long period of its maturation - as an addition rather than a replacement for distributive pension provision.

It should be borne in mind that although the funded pension system does not depend on the age structure of the population, it does depend on mortality. The funds accumulated in a person's pension account should be sufficient to replace labor income at an acceptable level for the remainder of his life. Consequently, the increase in life expectancy in retirement would call for increasing pension contributions, decreasing pensions or raising the retirement age. However, unlike in developed countries, in Russia the significance of these features is small, both because funded pensions are nascent and because the positive dynamics of life expectancy in retirement are very modest.

International organizations recommend the introduction of pension systems consisting of three pillars: distributive, mandatory funded and voluntary funded. All OECD States (with the exception of Hungary) follow this path, and in almost half of the member countries of this organization (including Australia, Great Britain, Italy, Mexico, New Zealand, Norway, Poland, Chile, Sweden and Switzerland), the main tasks have been completed.

In Russia, the State established in 2010 funded insurance, but did little to develop its voluntary (private) component, and the mandatory (public) component used the regulatory potential of the PFR to all but kill its private counterpart. Mandatory funding was done through channeling part of pension contributions ( $6 \%$ out of $22 \%$ of regular pension contribution) paid by employers "on behalf" of employees; the insured employee could invest additional amounts. The public funded pension system developed until 2014 and, by virtue of its compulsory nature, covered all employees born after 1966 (the cut-off year of birth changed three times) or 42 million people, but the accumulated resources were modest as a result of predominantly low wages, an incipient stage of development of the new type of pension, high inflation and extremely conservative investment policy.

In 2014, to reduce the transfer from the federal budget aimed at balancing of the MPI budget, mandatory funded pensions were "frozen", that is, the source of their growth (6-percent contributions) was blocked. Citizens' trust in this pillar of the pension system was undermined 
before it had formed, and the Government did not even hint at the possibility of any compensation for confiscated savings. Public mandatory insurance could, of course, be reinstated with a single decree, which would go unnoticed as long as overall pension contributions do not increase. But the suggested formation of a voluntary public pension fund will be hindered by a lack of public confidence and an unwillingness to further limit disposable income. The solution to the problem may be to restore the fixed separation of unchanged total contributions into distributive and cumulative parts when the insured themselves have the right to choose a pension fund (public or private).

From the onset, public financial institutions tried to crush private pension provision and prevent shifts in overall management of funded pensions to the benefit of private financial institutions. New regulatory mechanisms were created in haste and without taking into account world experience. As a result, they did not so much protect the interests of contributors and beneficiaries as limit the possibilities of private ("non-State") pension funds (NPF) and increase transaction costs. Moreover, the weak popularization of private pension insurance was combined with corruption scandals. Despite this, NPFs are developing: in less than a decade, the share of employees with accounts in NPFs has increased from zero to $10 \%$, and the average amount of accumulated contributions has reached 170 thousand rubles, which roughly equals 10 months of an average distributive pension. In 2017, 1.5 million people received pensions from pension funds for a total of 60 billion rubles (Pension Fund 2018). However, the achieved level of development of private pension insurance is quite modest. If, on average, in OECD member countries the ratio of NPF assets to gross domestic product in 2016 amounted to $86 \%$, in Russia it was only $5 \%{ }^{17}$.

\section{EXTERNAL RESERVES OF PENSION SYSTEM DEVELOPMENT}

The scale of external resources of the MPI system's income generation is an order of magnitude larger than that of internal ones. The increase in the labor force in ways other than RRA and the increased productivity would be more than enough (individually, and even more so if combined) to compensate for the natural decline in the labor force or, from a different perspective, to replace the RRA as a way to increase labor resources.

In Russia, the level of economic activity of the working-age population is significantly lower than in many developed countries. One of the main reasons is the inability to find work in many cities and rural areas with a low level of geographical mobility. This impossibility predetermines the fact that many working-age people simply do not enter the labor market, which depresses official unemployment rates. Meanwhile, an increase in employment can to a large extent compensate for the effect of the demographic factor, i.e. an increase in the number of retirees, and therefore be an alternative to raising the retirement age. Poland's experience shows that the equalization of conditions for retirement (mainly the reduction since 2009 of the number of categories of workers eligible for early retirement) has contributed more to employment growth than the RRA conducted in 2013 (Chłon-Domińczak, Strzelecki, Łątkowski 2016). Potentially,

17 The OECD estimate is borrowed from (OECD 2017). The estimate for the Russian Federation is calculated from (Pension \& Actuarial Consulting and the Russian Association of Non-State Pension Funds 2017). 
there are more such benefits in Russia than in Poland, and the corresponding categories of workers number in the millions.

Another basic factor is labor productivity. Neither the Russian level of labor productivity nor the rate of its growth (negative in some years) can be considered satisfactory. For instance, in 2018 average labor productivity per worker was (in 2010 prices) in Russia 25 thousand dollars per year, as compared with 83 thousand dollars in the European Union and 113 thousand dollars in the United States. Assuming that labor productivity in Russia will increase at a constant rate of $1 \%$ per year, then by 2030 it will reach $\$ 30,000$, which corresponds to the current average level in the G20. Even such a modest increase in labor productivity would provide the same positive macroeconomic dynamics as would be expected from an increase in the workforce due to RRA (provided that the increase is absorbed in the national economy)

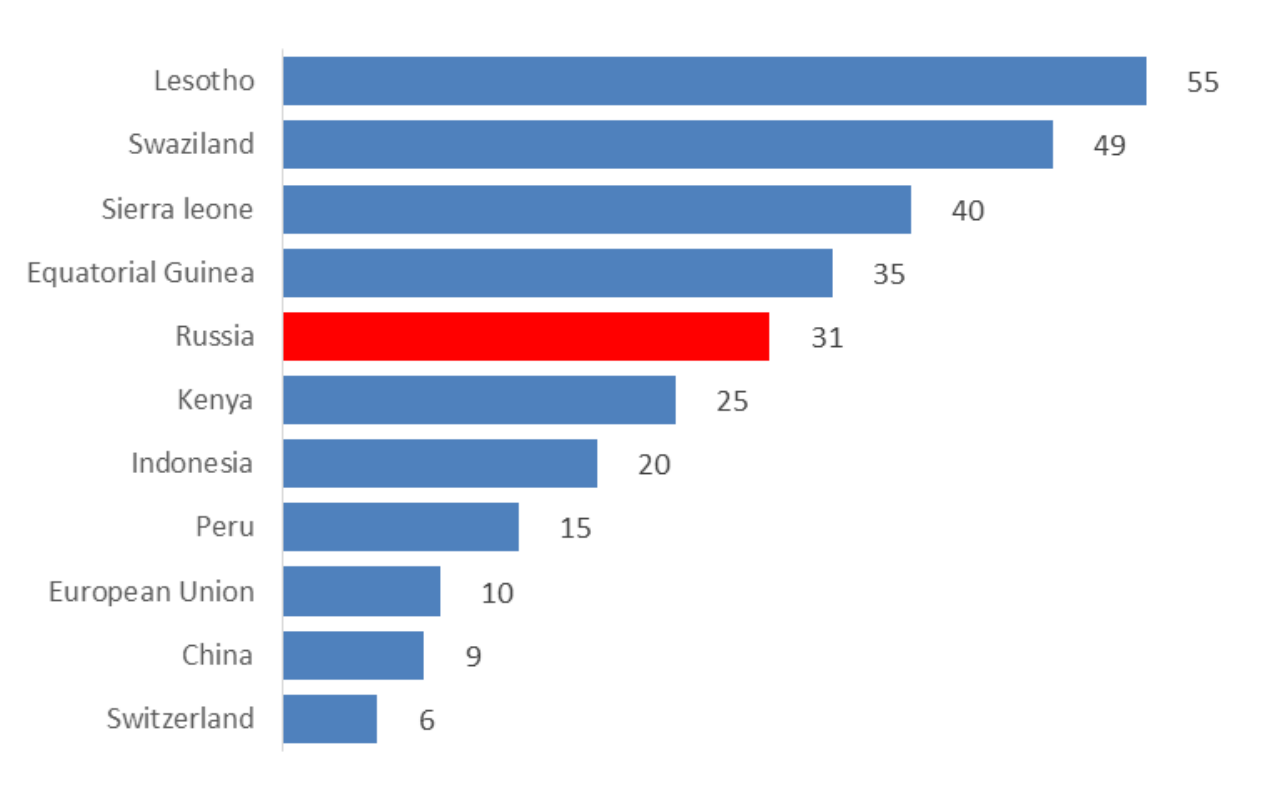

\section{Figure 13. The proportion of 15 -year-old boys dying before reaching age 60 in Russia and selected countries, 2015-2020, in percent}

Source: United Nations (2017).

Russia has a specific huge reserve for growth in the number of employed which is not available to developed countries. The country has a scandalously high mortality rate of adult men. For women, the situation is not brilliant either, but their life expectancy is 10 years higher then men's. The extremely high mortality rate among men of working age has been a feature of Russian society for a century. Unlike the rest of the world, Russian male mortality at working age, if it has changed, several times has done so for the worse, only to then return to an almost unnoticeable ascending trend. If the risks of dying during working life do not decrease, then almost $31 \%$ of those born in 2003 (15-year-old boys in 2018) will not live to their 60th birthday (and over a third will not live to age 65), while, for example, in Switzerland this share is 5\%. Fig. 13 compares Russia with selected countries with respect to this indicator.

A reduction in male mortality, even if not to the European, but at least to the Peruvian level, would give a much larger increase in labor resources than RRA. It is also clear that this is not easy to achieve, and that regular medical check-ups and propaganda for jogging, while useful, are far 
from enough. The root causes of high mortality are deep. For Russia, it is especially important to reduce mortality from cardiovascular diseases and external causes of death (murders, suicides, traffic accidents, work-related injuries, accidental alcohol poisoning, etc.), but this is hampered by unfavorable features of a lifestyle rooted in large social groups - in particular, the well-known alcohol abuse.

In recent years, there have been positive changes in mortality rates, but it is wrong to mechanically extrapolate them to the future: strengthening favorable trends will require comprehensive social development, increased employment, higher incomes, the launching of social lifts and a decrease in inequality with respect to living conditions in social and territorial dimensions. The health care system has proven capable of ensuring progress in some areas, but at the same time, its endless reform is counterproductive, especially against the background of insufficient funding: with per capita public health expenditures one-fourth of Germany's, it is impractical to count on approaching German results (Vishnevsky et al. 2006).

\section{CONCLUSION}

Does all the above mean that the retirement age, which in Russia before the reform was especially low, shouldn't be raised at all? No, it doesn't. The aging of the population is a general and fundamental trend which in the long run will certainly lead to a faster growth of liabilities of the MPI system in comparison with the dynamics of its own resources. If you do not resort to either a reduction in pensions, or to an increase in contributions (via increasing their rate or improving collection), or to external resources (transfers from the State budget), then there really are no alternatives to RRA. The problem is that in the context of reform, these alternative measures were not even considered. At the same time, the Russian RRA model is distinguished by the following characteristics.

First, the wrong reform scheme was chosen. The difference between the Russian version of pension reform and the already proven more gradual and milder RRA schemes is the source of plausible and hardly soluble conflicts in the near future.

Secondly, the timing of the reform is dubious. The dynamics of the age structure in the coming years will, by disrupting the smoothness of population aging, in themselves reduce the obligations of the PFR. On the other hand, the high adult mortality rate does not suggest that Russia is ready for significant RRA.

Thirdly, RRA does not completely solve the problem of the MPI system's deficit. From this it follows that the need for transfers will continue, which in itself is not so bad, since there are oil and gas resources, and the NWF was created specifically to finance the deficit of the PFR.

Fourthly, it is necessary to correlate financial revenues with their social price. Obviously, in this sense, the reform was not thought through, although thinking it through was both necessary and possible. A paradigm that deals with trillions of rubles without taking into account the millions of people affected should give way to a more sensitive approach. Alternatively, the socio-political cost of mistakes could be high. Foreign experience of pension reforms based on multivariable models of pension provision is both abundant and readily available. 
Fifth, in developing an integrated approach to pension reform, it would be necessary to look for eventual synergies. For example, a decrease in alcohol consumption can be both a factor and a consequence of increased economic activity. The development of cardiological care will raise participation in the workforce, and the improvement of working conditions will reduce morbidity. These and many other interconnections should be measured, their possible contribution to an increase in the flow of resources to the MPI system determined, and on this basis a budget should be elaborated and coherently implemented by the executive branch.

Sixth, funded pensions, which in other countries have proved to be highly effective as protection against population aging, are taking root poorly in Russia.

Seventh, it is known that the financial literacy of the population contributes to the approval of the reform by citizens and, in particular, mitigates its impact on electoral behavior (Fornero, Lo Prete 2019). In order to take advantage of this dependence, government officials and the media should be able to correctly comment on the reform, which was also not observed.

Eighth, neither academic institutions nor specialized government departments have sufficiently worked out the theoretical and practical issues of the RRA. Characteristically, despite wide public discontent, the announcement of RRA was not accompanied by a statement on mitigating measures. It seems that subsequent decisions, such as criminalizing the dismissal / refusal to hire people of pre-retirement age or introducing increased unemployment benefits, were hastily developed post factum.

A large stratum of problems that have attracted the attention of researchers in Europe, America, and Asia remains out of sight of Russian scientists. Along with the issues raised above, they include the political, economic and actuarial aspects of pension reforms; international comparisons of pension systems and pension reforms; relationships of the pension system with intergenerational flows of resources as well as with decisions to continue working after reaching retirement age; the age-specific ability to work and the health effects of work in older ages. Perhaps the most pressing task is the development of an integrated approach to pension reform which is not limited to any one parameter, no matter how important.

In addition, an understanding of the socio-economic context of reform and its consequences can be significantly improved by an adequate information base. For example, the dynamics of the Contingent and its characteristics could be more correctly assessed on the basis of the dynamic series of employment and wages in one-year age-sex groups: the absence of such information forced us to use rough (possibly incorrect) assumptions that the employment rates of one-year and five-year groups are equal, and that all employed members of the Contingent receive a national average pension. Direct information on the sources and magnitude of the Contingent's income would make it possible to adequately assess the need for Government assistance.

Pension problems cannot be solved in the margins of economic strategies. They should be approached with full cognizance of universal mechanisms that determine the demographic trends as well as national specifics. Successful pension reforms are integrated into economic strategies. Much can be done by adopting while adapting foreign experience, research and data collection practices. Otherwise, there is a great danger of getting something very different from what is desired, and repeatedly making the same mistakes. 


\section{REFERENCES}

Andreev E.M, M. McKee, V.M. Shkolnikov (2003). Health expectancy in the Russian Federation: a new perspective on the health divide in Europe // Bulletin of the World Health Organization vol. 81 (11) pp. 778-788. URL: https://www.who.int/bulletin/volumes/81/11/en/Andreevarabic1103.pdf

Arbati E., Feher C., Ree J.J.K., Saito I., Soto M. (2016). Automatic adjustment mechanism in Asian pension systems // International Monetary Fund: IMF Working Paper WP/16/242. URL: https://www.imf.org/en/Publications/WP/Issues/2016/12/31/Automatic-AdjustmentMechanisms-in-Asian-Pension-Systems-44460

Blake H., Garrouste C. (2017) Collateral effects of a pension reform in France. HAL: Id: hal01500683 URL: https://hal.archives-ouvertes.fr/hal-01500683v2

Carone G., Eckefeldt P., Giamboni L., Laine V., Pamies S. (2017). Pension reforms in the EU since the early 2000's: Achievements and challenges ahead // European Economy Discussion Paper No 42. URL: https://ec.europa.eu/info/publications/economy-finance/pension-reformseu-early-2000s-achievements-and-challenges-ahead_en

Chłoń-Domińczak A., Strzelecki P., Łątkowski W. (2016) Labour market and old-age transfers: Measuring the cohort effects of the pension reforms in Poland using APC approach. URL: http://international-pension-workshop.com/wp-content/uploads/papers-14/ChlonDominczak_1.pdf

De Grauwe, P. and M. Polan (2003) Globalisation and social spending // CESifo Working Paper No. 885. URL: https://www.ifo.de/DocDL/cesifo_wp885.pdf

Denisenko M.B., Ovcharova L.N., Varshavskaya E.Ya. pri uchastii [with the participation of] Vasin S.A., Kozlov V.A. (2018). Demograficheskiy kontekst povysheniya vozrasta vykhoda na pensiyu. Doklad gosudarstvennogo universiteta - Vysshaya shkola ekonomiki.

[Demographic context of raising age of retirement. Paper of the State University - Higher School of Economics]. DOI: https://doi.org/10.17323/demreview.v5i1.7708

Fornero E., Lo Prete A. (2019). Voting in the aftermath of a pension reform: The role of financial literacy // Journal of Pension Economics and Finance Vol. 18(1), pp. 1-30. DOI: https://doi.org/10.1017/S1474747218000185

Gietel-Basten S., Mau V., Sanderson W., Scherbov S., Shulgin S. (2017). Ageing in Russia: Regional inequalities and pension reform // HKUST IEMS Working Paper No. 2017-49 URL: https://iems.ust.hk/assets/publications/working-papers-2017/iemswp2017-49.pdf

Grech A.G. (2013). Pension policy design changes in EU countries since the mid-1990s // International Journal of Social Welfare Vol. 34 Issue 3, pp. 296-304.

DOI: https://doi.org/10.1111/ijsw.12138

Grishchenko N. (2016). Pensions after pension reforms: A comparative analysis of Belarus, Kazakhstan and Russia // Procedia Economics and Finance Vol. 36, pp. 3-9.

DOI: https://doi.org/10.1016/S2212-5671(16)30010-7

Gurvich Ye.T. Long-term demographic challenges and pension policy // Journal of the New Economic Association. 2011. № 9. P. 193-196. (In Russ.).

Hessel P. (2016). Does retirement (really) lead to worse health among European men and women across all educational levels? // Social Science and Medicine. Vol. 151, pp. 19-26.

DOI: https://doi.org/10.1016/j.socscimed.2015.12.018 
Holzmann R. and Stilitz J.E. (2001). New ideas about old age security: toward sustainable pension systems in the 21 st century. Washington DC: World Bank Group. URL: https://openknowledge.worldbank.org/handle/10986/13857

Ivanov S. (2010). Demographic and economic factors of labour supply: long-term projections and policy options for France, Germany, Italy and the United Kingdom. // Vienna Yearbook of Population Research. DOI: https://doi.org/10.1553/s83

Ivanov S. (2016). Obespecheniye zdorovogo obraza zhizni i sodeystviye blagopoluchiyu dlya vsekh v lyubom vozraste [Ensuring a healthy lifestyle and promoting well-being for all at any age] // L. Grigor'yev i S. Bobylev, eds. Tseli ustoychivogo razvitiya OON i Rossiya: Doklad o chelovecheskom razvitii v Rossiyskoy Federatsii 2016 [The UN Sustainable Development Goals and Russia: Human Development Report 2016 in the Russian Federation]. Moscow: Analiticheskiy tsentr pri Pravitel'stve Rossiyskoy Federatsii (Analytical Centre of the Government of the Russian Federation. P. 151-173). (In Russ.). URL: http://ac.gov.ru/files/publication/a/11068.pdf

Kak preodolet' otstavaniye Rossii po prodolzhitel'nosti zhizni [How to overcome the backlog of Russia in life expectancy]. (2016) Demographic Review 2(3), 154-201. (In Russ.). DOI: https://doi.org/10.17323/demreview.v2i3.1778

Klepikova E.A. and M.G. Kolosnitsyna (2017). Ageism at the Russian Labour Market: Wage Discrimination. Russian Management Journal 15 (1): 69-88. (In Russ.). URL: https://publications.hse.ru/mirror/pubs/share/direct/211147500

Kudrin A. and E. Gurvich (2012). Stareniye naseleniya i ugroza byudzhetnogo krizisa [Population aging and the threat of a budget crisis] Voprozy ekonomiki [Economic issues]. 3: 52-89. DOI: https://doi.org/10.32609/0042-8736-2012-3-52-79.

Levada Center (2018). Press Release September 27: Pensionnaya reforma [Pension Reform]. URL: https://www.levada.ru/2018/09/27/pensionnaya-reforma-4/

OECD (2017). Pensions at a Glance 2017: OECD and G20 Indicators, OECD Publishing, Paris. DOI: https://doi.org/10.1787/pension_glance-2017-en

Pension \& Actuarial Consulting and Russian Association of Non-State Pension Funds (2017). Pension Savings in Russia. Results of 2016 and interim results of 2017. (In Russ.). URL: http://p-a-c.ru/124237

Remington T.F. (2018). Institutional change in authoritarian regimes: Pension reform in Russia and China // Problems of Post-Communism (online edition). URL: https://www.tandfonline.com/doi/full/10.1080/10758216.2018.1450154

Schwarz A.M., Aria O.S., Zviniene A., Rudolph H.P, Escardt S., Koetti J., Immervoll H., Abels M. (2014). The inverted pyramid: Pension systems facing demographic challenges in Europe and Central Asia // Europe and Central Asia Reports. Washington DC: The World Bank. URL: http://www.worldbank.org/content/dam/Worldbank/Feature\%20Story/ECA/ECAPensions-Report-2014.pdf

Shulgin S.G., Zinkina Yu.V., S.Ya. Scherbov S.Ya. (2018). Ozhidayemaya prodolzhitel'nost' zhizni pozhilykh $v$ Rossii v zavisimosti ot obrazovatel'nogo statusa [Life expectancy of the elderly in Russia depending on the educational status]. Demographic Review 5(1) 25:38. (In Russ.). doi: https://doi.org/10.17323/demreview.v5i1.7708

Tyuryukanova E. (2006). Deshevyy trud - mif ili real'nost' [Cheap labor - myth or reality?] (In Russ.). Demoscope-Weekly 315-316. URL: http://www.demoscope.ru/weekly/2008/0315/tema05.php 
United Nations (2017). World population prospects. The 2017 revision. URL: https://population.un.org/wpp/

United Nations (2019). The 2019 Revision of World Population Prospects. The 2019 Revision. URL: https://population.un.org/wpp/

Vishnevkiy A.G., Ya.I. Kuz'minov, V.I. Shevskiy, S.V. Shishkin, L.I. Yakobson, Ye.G. Yasin (2006). Rossiyskoye zdravookhraneniye: kak vyyti iz krizisa. Doklad gosudarstvennogo universiteta - Vysshaya shkola ekonomiki. [Russian health care: how to get out of the crisis]. Paper of the National Research University - Higher School of Economics] Moscow: NIUVShE. (In Russ.). URL:

https://www.hse.ru/data/309/462/1237/Доклад_pocc\%20здравоохранение_2006.pdf

Yermo, J. (2012). The role of funded pensions in retirement income systems: Issues for the Russian Federation. OECD Working Papers on Finance, Insurance and Private Pensions, No. 27, Paris: OECD Publishing. URL: https://www.oecd-ilibrary.org/finance-andinvestment/the-role-of-funded-pensions-in-retirement-income-systems_5k9180xv25xw-en

\section{OFFICIAL STATISTICS OF THE RUSSIAN FEDERATION}

\section{Federal State Statistical Service (Rosstat)}

The Demographic Yearbook of Russia. 2017: Statistical Handbook. Rosstat. - Moscow, 2017. URL: http://www.gks.ru/bgd/regl/B17_16/Main.htm

Rabochaya sila, zanyatost' i bezrabotitsa v Rossii - 2018 g. [Labor, employment and unemployment in Russia 2018] Statisticheskiy sbornik [Statistical Handbook]. Rosstat 2019. URL: http://www.gks.ru/bgd/regl/b18_61/Main.htm

Russian Statistical Yearbook. Statistical Handbook. Moscow, Rosstat. (In Russ.). URL: http://www.gks.ru/bgd/regl/b03_13/Main.htm http://www.gks.ru/bgd/regl/b06_13/Main.htm http://www.gks.ru/bgd/regl/b10_13/Main.htm http://www.gks.ru/bgd/regl/b17_13/Main.htm

Sotsial'noye polozheniye i uroven' zhizni naseleniya Rossii - 2015 g. [Social status and standard of living in Russia - 2015]. Statisticheskiy sbornik [Statistical handbook]. Rosstat 2016. (In Russ.). URL: http://www.gks.ru/bgd/regl/B15_44/Main.htm

Trud i zanyatost' $v$ Rossii-2003, 2005, 2009, 2013, 2015, 2017 [Labor and employment in Russia 2003] Statisticheskiy sbornik [Statistical handbook]. Rosstat (In Russ.). URL:

http://www.gks.ru/bgd/regl/B03_36/Main.htm

http://www.gks.ru/bgd/regl/B05_36/Main.htm

http://www.gks.ru/bgd/regl/B09_36/Main.htm

http://www.gks.ru/bgd/regl/B13_36/Main.htm

http://www.gks.ru/bgd/regl/B15_36/Main.htm

http://www.gks.ru/bgd/regl/B17_36/Main.htm

\section{Ministry of Finance of the Russian Federation}

Flows of resources of the Fund of National Wellbeing. Retrieved September 21, 2018 from:

URL: https://www.minfin.ru/ru/perfomance/nationalwealthfund/ statistics/\#ixzz5MGN4LLxD. 


\section{Pension Fund of the Russian Federation}

Godovye otchety za 2011-2017 gody [Annual Reports, 2011-2017]. URL:

http://www.pfrf.ru/files/id/about/2011_godovojotchet.pdf

http://www.pfrf.ru/files/id/about/2012_godotchet.pdf

http://www.pfrf.ru/files/id/about/godovoi_otchet2013.pdf

http://www.pfrf.ru/files/id/press_center/godovoi_otchet/godovoi_otchet_2014_1.pdf

http://www.pfrf.ru/files/id/press_center/godovoi_otchet/Pension_fund_Annual_report_2015_ 1.pdf.pdf

http://www.pfrf.ru/files/id/press_center/godovoi_otchet/Annual_report_2016_3.pdf

https://www.pfrf.ru/files/id/press_center/godovoi_otchet/annual_report_2017_1.pdf 